\title{
Hedonic pricing with redevelopment options: A new approach to estimating depreciation effects
}

John M. Clapp

University of Connecticut, john.clapp@business.uconn.edu

Katsiaryna Salavei

Fairfield University, kbardos@fairfield.edu

Follow this and additional works at: https://digitalcommons.fairfield.edu/business-facultypubs NOTICE: this is the author's version of a work that was accepted for publication in Journal of Urban Economics. Changes resulting from the publishing process, such as peer review, editing, corrections, structural formatting, and other quality control mechanisms may not be reflected in this document. Changes may have been made to this work since it was submitted for publication. A definitive version was subsequently published in Journal of Urban Economics [67, 3, 2010] DOI: 10.1016/j.jue.2009.11.003

\section{Peer Reviewed}

\section{Repository Citation}

Clapp, John M. and Salavei, Katsiaryna, "Hedonic pricing with redevelopment options: A new approach to estimating depreciation effects" (2010). Business Faculty Publications. 18.

https://digitalcommons.fairfield.edu/business-facultypubs/18

\section{Published Citation}

Clapp, John M. and Katsiaryna Salavei. 2010. Hedonic pricing with redevelopment options: A new approach to estimating depreciation effects. Journal of Urban Economics 67 (3) 362-377.

This item has been accepted for inclusion in DigitalCommons@Fairfield by an authorized administrator of DigitalCommons@Fairfield. It is brought to you by DigitalCommons@Fairfield with permission from the rightsholder(s) and is protected by copyright and/or related rights. You are free to use this item in any way that is permitted by the copyright and related rights legislation that applies to your use. For other uses, you need to obtain permission from the rights-holder(s) directly, unless additional rights are indicated by a Creative Commons license in the record and/or on the work itself. For more information, please contact digitalcommons@fairfield.edu. 


\title{
Hedonic Pricing with Redevelopment Options: A New Approach to Estimating Depreciation Effects
}

\author{
John M. Clapp* \\ University of Connecticut \\ Center for Real Estate \\ John.Clapp@uconn.edu \\ and \\ Katsiaryna Salavei \\ Fairfield University \\ ksalavei@mail.fairfield.edu
}

November 17, 2009

\begin{abstract}
The standard hedonic model of durable assets is a special case of a more general model that contains two additive terms: 1) use value of the existing hedonic vector and 2) the value of the option to reconfigure hedonic characteristics. One empirical implication is that the two parts of value are related: e.g., use value increases with interior area whereas option value decreases with "intensity," the ratio of structure value divided by land value. Increases in building age reduce use value but increase option value. Data from Greenwich Connecticut indicate that intensity has the expected negative effect. Coefficients on building age are shown to be better measures of depreciation when intensity variables are included in the regression.
\end{abstract}

EconLit Subjects: D120, D460, G130, R310.

* Corresponding author. 2100 Hillsdale Road, Unit 1041RE, Storrs, CT 06269-1041. Phone: (860) 4863227.

The authors thank Will Strange and two anonymous referees for carefully reading the manuscript and suggesting many improvements. We are grateful to Greenwich Town Assessors Ted Gwartney and Bob Shipman for providing and explaining the data. Additional helpful suggestions were received from Dan McMillen, Stefano Gubellini and participants in a workshop at the AREUEA Meetings in San Francisco, January 2009, FMA Meetings in Reno, Nevada, October 2009 and SFA Meetings in Captiva, Florida, November 2009. The paper previously circulated under the title "Building Age, Depreciation and the Value of Redeveloping Property Characteristics.” 
Hedonic pricing with redevelopment options

\section{Introduction}

Durable assets are typically sold in pre-packaged bundles of attributes with asset value measured by the product of each attribute and its implicit market price (Rosen, 1974). ${ }^{1}$ Rosen's theory has spawned an immense literature aimed at estimating those attribute prices for a variety of goods or services such as the supply of labor, automobiles, art objects, municipal bonds and real estate (See for example, Ekeland, Heckman and Nesheim, 2003; Arguea and Hsiao, 1993; Gunnelin and Soderberg, 2003). In general, this literature uses a sample of market sales where one observes the sale price of the asset (the market value of the full bundle) and a vector, $q$ of attributes for each transaction. Given these data, the analyst regresses the bundle price (or the natural log of price) on attributes $q_{j},(j=1, \ldots, n)$ as indicated in equation (1).

$$
P_{i}=v^{\prime} q_{i}^{0}+\varepsilon_{i}
$$

where $i$ indexes $M$ individual property sales in cross-section, each with $n$ hedonic characteristics; $\mathrm{v}\left(q_{i}^{0}\right)$ is an $n$-dimensional column vector of implicit market prices (property characteristics) as of time 0 . The disturbance term arises from negotiations between buyers and sellers who have idiosyncratic characteristics. Thus, $\varepsilon_{i}$ is typically assumed to be iid. Rosen (1974) derived conditions for $v_{j}$ to measure implicit market price.

How does this model change if we allow the owner of the durable asset to alter the characteristic vector (i.e., redevelop the asset) at some cost, where cost is assumed to be strictly positive? In this case, any changes to price, random or deterministic, or

\footnotetext{
${ }^{1}$ One of the more restrictive assumptions is that markets for each attribute are sufficiently deep to allow implicit equilibrium prices to be determined: i.e., many buyers and sellers are present for each possible vector. This assumption has been relaxed by Harding, Rosenthal and Sirmans (2003).
} 
depreciation of quantity may be associated with redevelopment of $q_{i}^{0}$ to a different level. $^{2}$ We motivate the addition of another term to equation (1) for the value of this option, the right but not the obligation to change the characteristic vector. Option value includes the expected net present value (possibly zero, but necessarily non-negative) of the asset as reconfigured at the time the redevelopment option is exercised. For example, it is common in some housing markets to see demolition of smaller older houses and reconstruction of "McMansions” at a much higher intensity, the exercise of a call option.

Because of our focus on teardowns or substantial renovations we define the "intensity" of existing characteristics as a scalar aggregation index for the amount of structure per unit land value. The aggregator variable increases with interior square footage and other amenities (e.g., bathrooms, fireplaces or a pool) and decreases with building age and with land value. ${ }^{3}$ Theory demonstrates that use value (i.e., standard hedonic value when option value is near zero) increases and option value decreases with the aggregator variable.

The purpose of this study is to provide empirical evidence that, in the absence of correctly-specified variables for option value, hedonic estimates of implicit market prices will be biased. Specifically, variables such as building age and lot size are likely to capture some of the omitted option value; the direction of bias will be analyzed here. Intuitively, the coefficient on age measures depreciation (i.e., reduced asset value due to aging) for new structures that are near optimal size (see Malpezzi, Ozanne and

\footnotetext{
${ }^{2}$ Depreciation makes investment partially reversible. The value of the option to redevelop follows from partial or total irreversibility: it is costly to change the characteristic vector.

${ }^{3}$ Capozza and Li (1994) show that location is an important determinant of the value of the development option. In their monocentric model, development takes place on the urban fringe. One contribution of our paper is to construct a measure of intensity that includes location value, and to show that low intensity (e.g., an older, centrally located structure) may trigger redevelopment.
} 
Thibodeau, 1987). But the depreciation rate is smaller for an older structure or for any property with substantial option value, and it is irrelevant near the redevelopment time. Moreover, in the absence of a correctly specified option value term in the hedonic regression, the age variable may capture option value, so the hedonic regression may indicate that property value increases with age for older houses. ${ }^{4}$

Malpezzi, Ozanne and Thibodeau (1987) identify three problems with using the coefficient on building age to measure depreciation: 1) age is correlated with omitted location variables; 2) construction quality varies with age and older better quality units are more likely to survive; 3) land does not depreciate, and newer houses are built on land with higher value. In response, we use geocoded transactions to include numerous location variables in the regression, and we introduce land value explicitly into the option value term of our regression. ${ }^{5}$ It is our treatment of land value as part of the option value term that is our greatest departure from previous hedonic literature.

We use a certainty model with constant exponential depreciation to motivate the addition of an option value term to the standard hedonic regression, equation (1). In our model, depreciation, together with constant or increasing land value implies an optimal time for redevelopment to a new, higher level of intensity. Our model is closest to that of

\footnotetext{
${ }^{4}$ Increasing value for older properties is typical of hedonic studies: See Coulson and McMillen, (2008) and Goodman and Thibodeau (1995). The results of Malpezzi, Ozanne and Thibodeau (1987) are consistent with increases in option value for older houses: for renter (owner) regressions, 5 of 59 (9 of 59) metropolitan areas have nonnegative "depreciation" at 10 years of age. They point out that positive age effects may be explained because "the market may have been adjusting to shifts in households' demands" or to changes in supply (p. 384). Clapp and Giaccotto (1998) use a rational expectations framework to allow the age coefficient to change with shifts in supply and demand over time.

${ }^{5}$ The variation in construction quality with age is a measurement problem because older houses have often been substantially renovated, but their original construction date is the only one observed by the econometrician. Our empirical estimates use assessed structure value, which includes the assessor's estimates of property condition.
} 
Hedonic pricing with redevelopment options

Wheaton (1982), who allows durable capital to be replaced by newer, larger structure yielding higher rent. ${ }^{6}$

Any empirical test of hedonic theory with option value must deal with two major issues:

1. Appropriate measurement of the intensity of the existing vector;

2. How to specify a nonlinear regression so as to correctly identify use value and option value.

Functional form is highly relevant to model identification because option value depends negatively on the structure size and other desirable characteristics whereas these same variables enter positively into the use value portion of the model.

Our empirical results suggest that, in a market with only $1 \%$ to $3 \%$ option value for the median property, the bias in the age coefficient is substantial. Cumulative depreciation effects for a 20 year old property without much option value are underestimated by about 3 percentage points whereas those for a property with a lot of redevelopment potential are overestimated by about 6 percentage points. On the other hand, coefficients on lot size and interior area are not biased by economically significant amounts. In markets with more option value, one can expect to observe more bias in the coefficients. $^{7}$

The next section develops theory for the value of an embedded option to redevelop the vector of hedonic characteristics in equation (1). Section 3 analyzes the implications of the redevelopment option for the standard hedonic regression; it specifies

\footnotetext{
${ }^{6}$ Wheaton's model does not include depreciation, but new properties can have higher rent than old. When rent on new structures increases enough to compensate for construction costs, structures that were optimal under a previous rental regime will be replaced with higher amounts of capital per unit land.

${ }^{7}$ This conclusion follows from standard results for omitted regressor bias.
} 
a nonlinear hedonic valuation model. The data and empirical results are described in Section 4. Section 5 concludes.

\section{The Option to Redevelop and Structure Depreciation}

This section develops a simple theoretical framework motivating the importance of real option theory for the hedonic pricing model. In this framework, prices and interest rates are fixed - option value derives entirely from depreciation. In the model, the entire vector of hedonic characteristics depreciates at a constant rate $\delta \geq 0$ : i.e., we consider functional obsolescence and we abstract from different rates of depreciation for individual structural components. Building age enters our model in two ways: 1) in the standard hedonic regression where age is intended to capture depreciation; and 2) in an additional variable for the option term, where option value increases with age.

Equation (1) is a cross sectional hedonic regression, whereas real option theory is based on the present value of the future costs and benefits associated with redevelopment. Therefore, our first task is to show how the implicit prices in equation (1) are related to discounted present values.

The asset value of the vector of depreciating characteristics can be represented by the present value of the service flows discounted at constant rate $\rho>0:^{8}$

$$
P V\left(q_{i}^{0}\right)=\int_{0}^{\infty} p^{\prime} q_{i}^{0} e^{-(\delta+\rho) s} d s
$$

\footnotetext{
${ }^{8}$ Poterba (1984) exploits equation (2) in his study of taxes on owner occupied housing. Dreyfus and Viscusi (1995) allow for a finite life for hedonic characteristics.
} 
Hedonic pricing with redevelopment options

Time is indexed by $s$; the n-dimensional column vector of implicit spot rental rates per unit time is $p$ which is assumed constant, and the vector of hedonic characteristic at time 0 is $q_{i}^{0}(\geq 0) .{ }^{9}$ We can now derive the vector of implicit market prices, $v$ :

$$
v=p(\delta+\rho)^{-1}
$$

Property characteristics $q_{i}^{0}$ change only by depreciation until the owner decides to redevelop - i.e., exercise a one-time call option at cost $k$. This is an exchange option: at time $T$, the depreciated vector $q_{i}^{0} e^{-\delta T}$ is exchanged for a new larger structure characterized by the vector $q_{i}^{n}$. To keep the model simple, the new vector is predetermined, not optimally chosen. Then the hedonic model with a redevelopment option becomes:

$$
P_{i}=v^{\prime} q_{i}^{0}+\operatorname{Max}\left(\left\{v^{\prime}\left[q_{i}^{n}-q_{i}^{0} e^{-\delta T}\right]-k\right\}, 0\right) e^{-\rho T}+\varepsilon_{i},
$$

where the optimal $T$ is determined by maximizing $P_{i}$ with respect to $T$. The first term on the right hand side of equation (4) is the value of the existing vector (i.e., the use value of the property) and the second term is the value of the option to redevelop. Note that we estimate equation (4) at time $t=0$, when everything is known except $T$, which is optimally chosen.

Solving the first order condition, an equation for the optimal redevelopment time $T^{*}$, assuming that the parameters support $T^{*} \geq 0$, can be written as:

$$
v^{\prime} q_{i}^{n}=v^{\prime} q_{i}^{0} e^{-\delta T^{*}}[(\delta+\rho) / \rho]+k
$$

\footnotetext{
${ }^{9}$ Since quantity is measured as a stock, rental rates implicitly include the rate of service flow as well as rents per unit flow.
} 
The left hand side is the value of the new structure whereas the right hand side is a multiple of the depreciated value of the structure given up plus construction cost. At the time of redevelopment $\left(T^{*}=0\right)$ this differs from the NPV rule by the multiplier $(\delta+\rho) / \rho>1 .^{10}$ The value of the option to wait until $T^{*}$ can be evaluated relative to the NPV rule by $v^{\prime} q_{i}^{0} e^{-\delta T^{*}}\{[(\delta+\rho) / \rho]-1\}$. This is the amount by which the value of the renovated property differs from the strike price $\left(=v^{\prime} q_{i}^{0} e^{-\delta T^{*}}+k\right)$ at the time of redevelopment.

\section{Generalizations of the Certainty Model}

The purpose of the theory developed in this paper is to motivate the addition of an option term to the standard hedonic model. The certainty model, equation (4) makes it clear that the option value term decreases in the value of the existing structure, $v^{\prime} q_{i}^{0} e^{-\delta T}$ and in the cost to develop, $k$. Moreover, the option term is additive to standard hedonic use value, $v^{\prime} q_{i}^{0}$ and it must be nonnegative because redevelopment is a right and not an obligation.

This subsection point towards generalizing to the case where rent per unit of $q$ follows a stochastic process, possibly including jump processes (Boyarchenko, 2004), and the new vector of characteristics, $q_{i}^{n}$ is chosen optimally. Rather than deriving these equations, we motivate their plausible application to empirical work.

Consider an Ito process for the vector of spot rents represented by one element, $p_{j}, j=1, \ldots N:$

\footnotetext{
${ }^{10}$ Further explanation of a certainty model similar to this one can be found on p. 138 of Dixit and Pindyck (1994); p. 146 adds uncertainty in the context of Tobin's q. Rosenthal and Helsley (1994), use a stochastic calculus model that allows multiple redevelopment options to derive an equation similar to (5).
} 
Hedonic pricing with redevelopment options

$$
d p_{j} / p_{j}=\mu d t+\sigma d W
$$

where the rate of drift per unit time, $t$ is $\mu$ and $\sigma$ scales the variance of a standard Weiner process, $d W$. To avoid unnecessary notation, we assume that each of the $N$ rental prices follows the same stochastic process. ${ }^{11}$

We consider decisions to undertake substantial renovation or tear down and rebuild. This motivates our use of a scalar aggregator function, $q_{i}^{a}$, greatly simplifying the mathematics of stochastic calculus without sacrificing the basic idea behind equation (4). This implies that the vectors of implicit market prices and spot rents also reduce to scalars and that $v=p /(\rho+\delta-\mu)$. A more restrictive simplifying assumption is that property owners do not act strategically: i.e., redevelopment decisions are made myopically, without considering the response of other suppliers in the market. This assumption restricts application of the model to markets where there are many suppliers. $^{12}$

Given these simplifying assumptions and the stochastic process in equation (6), we propose the following solution where the new aggregate level of the hedonic vector, $q_{i}^{n}$ is chosen optimally:

$P_{i}=v q_{i}^{a}+B_{0}\left(q_{i}^{a}\right)^{B_{1}}+\varepsilon_{i}$ where $B_{1}<0, B_{0} \geq 0, v \geq 0$.

\footnotetext{
11 The certainty case can be generalized by adding drift at rate $\mu$; i.e., $\sigma=0$ : $P_{i}=v^{\prime} q_{i}^{0}+\left\{v^{\prime} e^{\mu T}\left[q^{n}-q_{i}^{0} e^{-\delta T}\right]-k\right\} e^{-\rho T}+\varepsilon_{i}$ where $\rho>\mu>0$. Now the optimal $\mathrm{T}^{*}$ is given by: $v^{\prime} q^{n} e^{\mu T^{*}}=v^{\prime} q_{i}^{0} e^{(\mu-\delta) T^{*}}[(\delta+\rho-\mu) /(\rho-\mu)]+k \rho /(\rho-\mu)$. As with equation (5), the strike price is multiplied by numbers greater than one at the time of redevelopment $\left(\mathrm{T}^{*}=0\right)$.

${ }^{12}$ For example, the model used here applies to housing, but not to office buildings in markets where there is a race to build the largest structure.
} 
The $B_{i}$ parameters are functions of the current level of price, the constant rate of interest $\rho$, the rate of depreciation $\delta$, the parameters of equation (6) and parameters of the cost function.

This paper does not prove equation (7), but it does establish its plausibility in two ways: 1) it is intuitively plausible; 2) the power function used for the second term is consistent with the literature on real options.

Intuitive plausibility follows from comparing equation (7) to equation (4). The first term of both equations is the expected value of the existing improvements if the option to redevelop is never exercised. This is use value, which increases with the existing level of the hedonic aggregator, $q_{i}^{a}$. The option (second) term says that value decreases with $q_{i}^{a}$ because strike price increases with the amount of existing rent sacrificed in order to build to higher intensity. For example, a property with a newly built structure will typically be near optimum, so the value of the option will be low, whereas a smaller older building on identically valued land will be associated with large option value. Unlike equation (4) the new level of intensity does not appear because it is optimally determined by the parameters of the model. The plausibility of $B_{0} \geq 0$ follows from the maximization problem: the property owner has the right but not the obligation to redevelop, so option value can never be negative.

Equation (7) is consistent with other models in the real options literature. McDonald and Siegel (1986) and Dixit (1989) derive power functions for real option value. Sick (1990, equations IV.7 - IV.11) derives a similar valuation equation for a dividend paying asset. In his model, the first term is the present value of an infinite stream of dividends and the second (option value) term declines with the present value of 
Hedonic pricing with redevelopment options

dividends, which are added to the cost of exercise. Likewise, in the Capozza and $\mathrm{Li}$ (1994) model, equilibrium development intensity is higher near the center of the city. Their model implies development at the urban fringe where intensity is zero (vacant land). This is consistent with our model: option value is highest where $q_{i}^{a}$ is lowest.

Clapp, Jou and Lee (2008) demonstrate that a minimum level of $q_{i}^{a}$ is implied by the model. Below that level, optimal redevelopment will have already occurred. ${ }^{13}$

Equation (7) has important new implications for cross-sectional hedonic models. The existing level of the hedonic aggregator function $q_{i}^{a}$ varies across different properties. This implies different amounts of option value, with the highest option value being in properties with the least amount of $q_{i}^{a}$.

\section{Implications for Hedonic Regressions}

\subsection{The Standard Hedonic and Omitted Variables Bias}

The standard hedonic model omits the second term of equation (7). This subsection uses a linearization to investigate omitted variables bias.

The second term of equation (7) can be approximated with a first order Taylor expansion around the average aggregate hedonic characteristic, $q_{i}^{a}$. This produces a single right hand side variable, $q_{i}^{a}$ the aggregate characteristic for each property $i$. But, the Taylor expansion shows that its coefficient is biased downward when compared to the

\footnotetext{
${ }^{13}$ Clapp, Jou and Lee (2008) derive equation (7) without depreciation, $\delta=0$. Williams (1997), equation (14) allows repeated redevelopment and $\delta \geq 0$. His option term is similar to equation (7); it involves a power function in the existing level of development, $x$.
} 
implicit market price of the hedonic characteristic, and that the constant term is upwardly biased. The Taylor expansion implies the following approximation to equation (7):

$$
\begin{aligned}
& P_{i} \approx k_{0}+\left(k_{1}+v\right) q_{i}^{a}+\varepsilon_{i} \\
& \text { where } v=p /(\rho+\delta-\mu)>0 \\
& \text { and } k_{0}>0, k_{1}\left(=B_{0} B_{1} q_{i}^{a\left(B_{1}-1\right)}\right)<0 .
\end{aligned}
$$

In equation (8), $v$ is the true implicit market price for the aggregate hedonic characteristic. The intuition behind equation (8) is that the average value of the omitted option term, the second term in equation (7), is captured in the constant, $k_{0}$, and it is necessarily nonnegative. The downward bias in estimated implicit market prices, the coefficient on $q_{i}^{a}$, follows immediately. The bias is negative $\left(k_{1}<0\right)$ because the second term in equation (7) varies negatively with $q_{i}^{a}$. As either $B_{0}$ or $B_{1}$ approaches 0 , the option term goes to a constant and the linear hedonic becomes a good approximation: i.e., $k_{1}$ in equation (8) approaches zero.

\subsubsection{Cross Sectional Variation in Building Age}

Exponential depreciation over time is explicit in equations (4) and (5). This subsection develops the implications of this for a cross sectional hedonic regression with properties of different ages. We do this by explicitly allowing variation in $q_{i}^{a}$ by age: i.e., redefine $q_{i}^{a}$ as a new property and introduce a depreciation term into equation (7):

$$
P_{i}=v q_{i}^{a} e^{-\delta \text { Age }_{i}}+B_{0}\left(q_{i}^{a} e^{-\delta \text { Age }_{i}}\right)^{B_{1}}+\varepsilon_{i}
$$

where $B_{1}<0, B_{0} \geq 0, v \geq 0, \delta \geq 0$.

Equation (7’) clarifies that, in cross section, older properties have more option value. Standard omitted variables analysis demonstrates that the coefficient measuring 
Hedonic pricing with redevelopment options

depreciation - the first term of equation ( $\left.7^{\prime}\right)$ - will be biased upward if the option value term is omitted. Intuitively, this is because the age variable will be positively correlated with omitted option value; older properties will be more valuable than would be justified by depreciation alone.

\subsubsection{Cross Sectional Variation in Land Value}

Urban economic theory implies that land value is a residual. In a world with malleable and infinitely divisible capital, where all structures are always optimal, land value is the present value of future net rents minus construction costs. Since land value is defined implicitly, it is not directly estimated from hedonic regressions.

Consider two properties with identical structures of identical age, one on high valued land and the other on low valued land. The property with high land value has more option value than the one with low land value. Land value enters the denominator of the option value variable. Thus, we propose the following cross-sectional model:

$$
\begin{aligned}
& P_{i}=v_{k} q_{i}^{a} e^{-\delta \text { Age }_{i}}+B_{0}\left(q_{i}^{a} L_{k}^{-1} e^{-\delta \text { Age }_{i}}\right)^{B_{1}}+\varepsilon_{i} \\
& \text { where } B_{1}<0, B_{0} \geq 0, v_{k} \geq 0, \delta \geq 0 .
\end{aligned}
$$

Here $L_{k}$ is land value at location $k$, and the implicit market price, $v_{k}$ varies by location.

Land value does not enter the first (use value) term of equation (9) explicitly because it is a residual. The present value of future rents, $v_{k}=p_{k} /(\rho+\delta-\mu)$ is higher in the high value neighborhood because $p_{k}$ is higher. Hedonic regressions typically control for variations in $v_{k}$ by including location characteristics in the vector of hedonic characteristics, or by allowing spatial dependence in the disturbance term. The different ways that land value is related to the two terms of equation (9) - implicitly as a residual 
in the first term, explicitly in the second - leads to a strategy for identifying the coefficients of the two terms: see discussion in the next subsection. ${ }^{14}$

In summary, we propose estimating two models, the standard linear hedonic model, equation (8) and the nonlinear model with option value, equation (9). The $v_{k}$ coefficient in equation (9) should correctly estimate the implicit price of the hedonic characteristic controlling for location $k$, whereas the coefficient on $q_{i}^{a}$ in equation (8) will generally be biased downward (upward for a negative characteristic such a building age). The next section disaggregates the hedonic vector and distinguishes it from intensity.

\subsection{Estimation Issues Associated with Equation (9)}

Special estimation problems associated with equation (9) include an identification issue: one term increases and the other decreases in a desirable characteristic. The second set of problems is associated with measurement of the aggregator variable $\left(q_{i}^{a}\right)$ as distinct from the standard hedonic vector.

\subsubsection{Identification and Functional Form}

One strategy for identification of the two terms in equation (9) is nonlinear restrictions. Specifically, the parameter $B_{0} \geq 0$ (i.e., option value cannot be negative) and $B_{1}<0$. The simulations conducted by Clapp, Jou and Lee (2008) demonstrated that

\footnotetext{
${ }^{14}$ The form of equation (9) may be viewed as counterintuitive when one considers that the expected value of the left hand side equals land value plus structure value whereas the term in parentheses on the right hand side can be interpreted as structure value (construction cost) divided by land value. We take the view that this is intuitive in the sense that the value of a real option is typically expressed as a function of some ratio involving $\mathrm{V}$ (the current value of the asset) and $\mathrm{V}^{*}$ (a critical value triggering investment). See Dixit and Pyndick (1994), p. 142.
} 
the two terms can be identified in this way even when few properties contain significant option value.

Statistical tests of these parameter restrictions depend on the functional form chosen for equation (9). We propose two criteria for functional form: 1) option value should be additive to the vector of hedonic characteristics; 2) the disturbance term should imply multiplicative errors. Each of these will be discussed next.

Additive option value is an essential feature of the model developed above, following directly from the optimization problem leading to equation (9). It is particularly important here, where our main interest is in estimation of the implicit market prices of the hedonic vector. Many properties (e.g., those newly built) will have near zero option value because they are already at the optimal level of the aggregator variable. In this case, it is important that property value not approach zero: i.e., standard hedonic use value, equation (1), remains.

A multiplicative error term is assumed when the log of sales price is the dependent variable, a functional form that has become commonplace in the hedonic literature. Semi log or double log hedonic models have the plausible characteristic that errors made by buyers and sellers are a percentage of underlying value, not constant dollar amounts. Previous empirical work has shown that heteroscedasticity is substantially reduced or eliminated by semi or double log models. Therefore, we will consider only models with log of sales price as the dependent.

Several functional forms are consistent with additive option value and multiplicative error term. A functional form that follows immediately from equation (9) with a multiplicative error term is: 
Hedonic pricing with redevelopment options

$$
\ln P_{i}=\ln \left(\alpha+v^{\prime} q_{i}^{0}+b I_{i}^{B_{1}}\right)+\varepsilon_{i}
$$

Where $I\left(=\left(q_{i}^{a} / L_{k}\right) e^{-\delta A g e_{i}}\right)$ is the aggregator variable, and $q_{i}^{0}$ and $v$ are the vectors of hedonic characteristics and implicit market prices defined for equation (1). ${ }^{15}$ Equation (10) will be difficult to estimate because it involves two levels of nonlinearity.

The literature typically estimates hedonic models with log of interior area and log of lot size. A polynomial function of building age is typically included (Malpezzi, Ozanne, and Thibodeau, 1987). A functional form that accommodates the standard hedonic specification and meets our two criteria is:

$\ln P_{i}=\alpha_{0}+\alpha_{1} \ln$ Footage $+\alpha_{2} \ln$ Lotsize $+\alpha_{3}$ Age $+\alpha_{4}$ Age $e^{2}+\alpha_{5} h+b I_{i}^{B_{1}}+\varepsilon_{i}$

Where $h$ is a vector of other characteristics such as number of baths and time dummies; Age is building age in years; Footage is interior area (square feet); and Lotsize is lot size (square feet). ${ }^{16}$ Equation (11) allows the aggregator variable, $I$, to be additive with the characteristic vector and pricing errors are multiplicative. A grid search across plausible values for $B_{1}$ provides one way to estimate equation (11). ${ }^{17}$

A third functional form that meets our two criteria is:

$$
\ln P_{i}=\alpha_{0}+\alpha_{1} \ln \text { Footage }+\alpha_{2} \ln \text { Lotsize }+\alpha_{3} \text { Age }+\alpha_{4} A g e^{2}+\alpha_{5} h+B_{1} \ln I_{i}+s B_{1}^{s} \ln I_{i}+\varepsilon_{i}
$$

\footnotetext{
${ }^{15}$ Note that we have not aggregated the hedonic vector for the purposes of use value, and building age is typically included in the vector. We retain $q_{i}^{a}$ for the purposes of identifying option value.

${ }^{16}$ Lot size is another hedonic characteristic that can capture some of the omitted option value term. A minimum lot size will be required to justify the fixed costs of redevelopment; however, the minimum size will be an empirical issue. Beyond the minimum, larger lots generally increase the ability to redevelop the property, so the coefficient on lot size would be biased upward by the omission of an option value variable. Note that lot size is included in standard hedonic specifications as an additional positively-valued characteristic. With a properly specified option term, the estimated coefficient on lot size should decrease.

${ }^{17}$ See Greene (2003), pp. 171-173 for an example very similar to the problem addressed here.
} 
Hedonic pricing with redevelopment options

where the $s B_{1}^{s}$ term shifts $B_{1}$ at low levels of the aggregator variable: e.g., $s$ is a dummy variable with a value of 1 over the lower $25^{\text {th }}$ percentile of $I_{i}$, otherwise zero. Consider the original model, equation (9) with $B_{1}=-.05$ and $I_{i}$ ranging from .01 to 2.0 , numbers supported by the Connecticut data. In this case option value decreases by about $25 \%$ over the lower quartile of intensity, then decreases by only $7 \%$ over the interval $.5 \leq I_{i} \leq 2$, a plausible representation of the nonlinearity inherent in option value. In equation (12) the lower quartile is shifted to compensate for the logarithmic transformation which otherwise requires a constant elasticity model. ${ }^{18}$

\subsubsection{Measurement of the Aggregator Variable}

The second major empirical issue deals with the measurement of the aggregator variable. In equations (10), (11), and (12) the standard hedonic specification is all the characteristics of the structure and lot. The issue is how to distinguish this from the term which declines with the aggregator variable, given that the aggregator variable is a positively-valued function of the vector of hedonic characteristics. Identification is more difficult if the aggregate measure is highly correlated with the hedonic characteristics in the linear term.

Specific intensity variables that exploit the above characteristics are:

1. Assessor-determined structure value divided by assessed land value for each observation (Intensity Assessor $).^{19}$

\footnotetext{
${ }^{18}$ Our empirical work will also need to allow for zero intensity, the case considered by Rosenthal and Helsley (1994).

${ }^{19}$ See precise definitions of all variables in Table 1.
} 
Hedonic pricing with redevelopment options

2. The ratio of interior square footage of subject property to the average interior square footage of nearby new construction $\left(\right.$ Intensity $\left._{\text {New Const }}\right){ }^{20}$

3. The percent of neighboring sales recently torn down or having teardown potential $\left(P_{\text {Teardown }}\right)$, where teardowns are identified by the town assessor.

Intensity calculated as the ratio of assessed building value to assessed land value (Intensity $_{\text {Assessor }}$ ) is consistent with real options theory because it identifies valuable lots and captures both physical and functional depreciation of property. It has been shown that assessors add information through careful inspection of the property and the use of hedonic regressions that include numerous location factors (See Clapp and Giaccotto, 1992). The assessor's valuations may be influenced by political pressure and the like, but appeals by property owners and statewide audits (sales ratio studies) limit the amount of error introduced. Most important for our research is that the assessor is able to observe whether the lot is suitable for development and assigns land value accordingly.

Real options theory suggests that new properties should be built at optimal intensity. ${ }^{21}$ Therefore, we construct our second measure of intensity as the ratio of interior square footage of subject property to the average interior square footage of

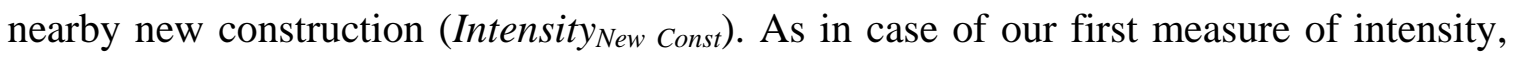
small value of Intensity $_{\text {New }}$ Const corresponds to large option value. But Intensity New Const does not control for the age, condition or land value specifically associated with the subject property. Therefore, we consider it only as a robustness check when compared to the intensity measure based on assessor data.

\footnotetext{
${ }^{20}$ We would like to thank the anonymous referee for suggesting this measure of intensity.

${ }^{21}$ Consistent with real option theory we find that our first measure of intensity is larger for new properties than for older properties (recall that larger intensity corresponds to smaller value of option to redevelop).
} 
Our last measure of intensity is the percent of nearby teardowns. This variable has the nonlinear call-option form required by theory, because many properties (e.g., in newer neighborhoods) will have few teardowns nearby whereas others will be in

neighborhoods experiencing substantial redevelopment. The presence of neighboring teardowns indicates that land value is high relative to structure value (i.e., intensity is low in the neighborhood). On the other hand, the percent teardown includes no characteristics of the subject property: it proxies only for high land value. We conclude that percent teardown supplements our first two measures of intensity.

\section{The Data and Results}

\subsection{Data for Greenwich Connecticut}

We test predictions of the model using data for single-family houses in Greenwich, Connecticut. Greenwich is an affluent town with median family income of $\$ 122,719$ in 2000 , compared to $\$ 53,935$ in the State of Connecticut and $\$ 50,046$ for the US as a whole. Of the population older than 25, 58.8\% have bachelor's or higher degrees, compared to $31.4 \%$ in the State of Connecticut and $24.4 \%$ for the US.

Sales data and property characteristics at time of sale are obtained from the Warren Group, publishers of Banker \& Tradesman, a business and real estate newspaper covering New England states (B\&T thereafter). They obtain the data monthly through visits and electronic connections with Connecticut town halls.

An important feature of our dataset is that it contains assessed land and structure values, which are used to calculate Intensity ${ }_{\text {Assessor. }}$ The Greenwich assessor maintains datasets for all properties that include detailed property and land characteristics that are 
not available through B\&T: see Table 2 for description of data collected by the assessor. Building value is estimated from tables that are developed using comparable properties. The property is assigned into one of 15 quality class categories. Adjustments are made for style, age, condition, number of baths, number of fireplaces, air conditioning, garages and other special features. Through this extensive research the assessor is able to identify properties suitable for redevelopment.

The assessor estimates land value by dividing the town of Greenwich into 49 neighborhoods, each having a different base land value, and adjusting the value for size, shape, topography, wet lands, traffic, railroad, highway, river view, river frontage, view of Long Island Sound, scenic views, proximity to the beach and a golf course, etc. We ran a regression of natural logarithm of assessed land value on location characteristics obtained from GIS, such as proximity to Long Island Sound, CBD, railroad, and highways (regression not shown). These location characteristics explain 58\% of assessed land value and have the same sign and similar magnitude to coefficients on location characteristics in a hedonic model, suggesting that location affects land value and sales price in the same way. We conclude that assessed land value adds important information not available from standard hedonic analysis.

Is lot size collinear with land value in a way that is related to option value ${ }^{22}$ Lot size by itself cannot correctly capture the value of the right to build for several reasons. First, lot size does not capture location characteristics of the property that are the key determinants of land value, while assessed land value does. Second, redevelopment on small lots can be done through addition of extra levels to the building or improved

\footnotetext{
${ }^{22}$ As discussed in section 3.1.2, lot size is one of the hedonic characteristics, analogous to extra space in the garage whereas land value explicitly enters the option value term of our model. Urban economic theory emphasizes the right to build on a standard lot, not lot size.
} 
architecture of current structure. For example, on Boston’s Beacon Hill people will install $\$ 100,000+$ kitchens in order to increase intensity on very valuable land. Third, much of the land around the property can be unsuitable for development because of wet lands or other topographical issues. Fourth, large lots may be more prevalent in less valuable locations. ${ }^{23}$ Consistent with these arguments, standard hedonic models find relatively small coefficient on lot size, suggesting that additional square footage adds little compared to interior area and that lot size does not capture land value. In our regressions, we do allow the possibility that unusually small lots constrain redevelopment potential.

Another advantageous feature of our dataset is the identification of residential properties sold in connection with a teardown. The identification is done by the town assessor based on demolition and building permits and on direct observation of the houses. It is the assessor's intention to identify properties that have land value only, but the date of teardown is open to question. The assessor says that "a sale occurs and 'shortly' thereafter the house is torn down. 'Shortly' is somewhat subjective and often includes some discussions between our appraiser and the owner." ${ }^{24}$ To further complicate the interpretation of "teardowns," our analysis of the characteristics of properties that sold more than once indicates that 52\% (=80 out of 154 multiple sales) did not exercise the teardown option as of the time of the later sale. ${ }^{25}$ We conclude that the assessor's identification of teardowns is an indication of past or future teardown potential, and we

\footnotetext{
${ }^{23}$ In fact, in Greenwich and the rest of southern Connecticut the area near New York City commuter railroad, which goes along Long Island Sound, is more valuable and has smaller lots than the area further to the north.

${ }^{24}$ Correspondence with Robert Shipman, Greenwich Town Assessor, February, 2008.

${ }^{25}$ In a number of cases, our data on property characteristics suggest that the property had already been redeveloped at the time of the "teardown" sale.
} 
expect this to add valuable information; but it is not a reliable indicator that the redevelopment option was actually exercised following the date of sale. ${ }^{26}$

There were 7,976 sales between 1994 and 2007 of single family residential properties with warrantee deed. The mean house price is over \$1.5 million. The mean sale year is 2000. The average house is built in 1945, has interior square footage of 2,855 and a lot size of over 50,000 square feet. We applied several data filters to arrive at the sample used in the analysis. We compared means of samples before the filter and after the filter using t-tests. First, we eliminated all houses (2,105 observations) that did not plot within Greenwich boundaries (see Table 3, Panel A). The resulting sample has higher mean sale price of $\$ 1.7$ million, but slightly lower interior square footage and lot size (2,792 and 47,031 square feet, respectively). These changes, which are statistically significant, reflect high land value and limited area for development within the town of Greenwich. ${ }^{27}$ The mean year the property was built did not change. The mean year of sale increased slightly to 2002.

Second, we applied a number of filters described in Table 3, Panel B to arrive at a sample of 5,218 that was used in regression analysis. Most observations were lost when we required the properties to be built after 1900 (467 observations). Some of these are typographical errors (e.g., the property reported as built in 1189); others were built in the $19^{\text {th }}$ century but were substantially renovated over the subsequent century. The sample in Panel B did not change in terms of sale price, interior square footage, lot size and year of

\footnotetext{
${ }^{26}$ Our teardown data differs from the data compiled by Rosenthal and Helsley (1994) and by Dye and McMillen (2007). The implications of this for our empirical work will be discussed below.

${ }^{27}$ We test statistical significance of the difference in means for Price, Footage and Lot size using a t-test. Changes in means of Year built and Sale year are not tested using a t-test because these variables do not follow a t-distribution and the changes are too small to justify a nonparametric test.
} 
Hedonic pricing with redevelopment options

sale. However, the mean year the house was built increased by 6 years to 1952, an indication of the extreme values eliminated.

Table 4 shows descriptive statistics for variables used in the analysis of the 5,218 sales. Panel A shows descriptive statistics for continuous variables, while panel B shows descriptive statistics for discrete variables. The average age of the house sales is 50 years, suggesting teardown potential. A number of properties might be described as "mansions," reducing their value as teardowns: nearly 30\% have more than 3 bathrooms and 23\% have five bedrooms or more. The mean ratio of assessed building value to assessed land value (Intensity Assessor $_{\text {) }}$ is close to one.

Our second measure of intensity is based on neighboring new construction. We define new construction as a property with age less than sixteen years. New construction has much larger interior square footage and lot size than the 5,218 sample. Mean Footage (Lot size) for new construction is 4,856 $(85,319)$ square feet compared to $2,768(46,450)$ square feet for the full sample. This is consistent with the prediction of real options theory that new construction is built at a higher optimal intensity, which is more likely to take place on bigger lots. The mean ratio of Intensity ${ }_{N e w}$ Const is 0.65: i.e., the average sale has interior area equal to $65 \%$ of that of surrounding new construction.

Our last measure of intensity is the percent of teardowns sold within 3 years and within 0.75 miles of each observation $\left(P_{\text {Teardown }}\right)$. The distribution of the percent of teardowns is similar to the typical option payoff. About $33 \%$ of properties have no teardowns within $3 / 4$ of a mile. The median (mean) sale has $2.4 \%$ (3.5\%) of neighboring sales involving teardowns. The upper part of the distribution is skewed with $10 \%$ having 
more than 8.5 percent of neighboring sales as teardowns; a few properties have more than $15 \%$ because of substantial geographical clustering of teardowns.

Table 5 shows selected characteristics for potential teardowns. The Greenwich town assessor identified 529 teardowns. We were able to match 233 of the teardowns to B\&T sales data, 219 of which plot within Greenwich’s boundary. Teardowns have higher mean price than the rest of the sample but the difference is not statistically significant. The interior square footage is $11 \%$ smaller for teardowns than for the B\&T sales data, while lot size is $23 \%$ greater (see Table 5, Panel A and Table 3, Panel A). These differences are significant at 5\% level or better. This corroborates industry reports that smaller houses on adequately sized lots are the most likely to be identified (by the town assessor in this case) as having teardown potential. The year built is similar for the two samples. Teardowns have a more recent sale year because the assessor did not collect data on teardowns before 1996. We cleaned teardown sample using the same filters applied to B\&T sales data. All characteristics changed by less than $1.11 \%$ and the changes were not statistically significant for any of the variables when we eliminated properties that were outside Greenwich boundaries (Table 5, Panel B).

\subsection{Results}

Table 6 compares the standard hedonic model to models that include terms for option value measured by the ratio of assessed building value to assessed land value. The standard hedonic, model 1 has the expected signs on all explanatory variables. ${ }^{28}$ All

\footnotetext{
${ }^{28}$ The coefficients on the annual date of sale dummies are suppressed. They show that house prices in Greenwich increased monotonically over the period from 1994 through 2007. House prices were about 112\% higher in 2007 than in 1994.
} 
standard errors are spatially clustered to control for spatial dependence, and they are calculated with Huber-White robust methods. $^{29}$

The key driver of value, the log of interior square footage, has a strongly significant positive sign with a coefficient (.67) well within the range of previous literature. Similarly, the log of lot size has a significant positive coefficient. The bathroom and bedroom variables are designed to identify unusually luxurious houses, those with more than three bathrooms or more than five bedrooms. These dummy variables are significant and add $8 \%$ and $6 \%$ to house value, respectively. ${ }^{30}$

The location variables are designed to capture variations in spot rents within the town of Greenwich: i.e., variation in $v_{k}$, equation (9). ${ }^{31}$ The location variables perform as expected, given that Cos Cob is a desirable neighborhood with restaurants, shops, and a harbor with access to Long Island Sound. Distance from Cos Cob Harbor has a significant negative sign and a location within one mile of the harbor adds over $17 \%$ to house value. Any property that might have a view of Long Island Sound, a variable that overlaps with the Cos Cob dummy, adds $8.5 \%$ to value. Being within 300 feet of a railroad track subtracts 7\% from value with marginal statistical significance.

The coefficients on the age variables in Table 6 are statistically significant and they show property value declining until about age 45, then rising. This is consistent with the pattern found in many other hedonic studies, including Coulson and McMillen (2008)

\footnotetext{
${ }^{29}$ Tables 6 and 7 cluster standard errors using a 65 cell grid placed over Greenwich. Cameron, Gelbach and Miller (2008) suggest that 65 clusters is enough to obviate the need for bootstrap methods.

${ }^{30}$ These percent changes and all similar calculations are equal to exp(coefficient)-1. We present $t$-values rather than standard errors because of our assumption that the market clears in terms of $\ln$ (Price) rather than Price. For those who want to think in terms of levels it will be necessary to calculate confidence intervals and calculate exponents of the end points.

${ }^{31}$ Greenwich has a separate municipal government with jurisdiction over property taxes and local public services such as schools, police, and fire. Therefore, we have controlled for these "Tiebout" variables.
} 
but the minimum point for the age function in their study of Chicago was about 70 years. Clearly, any increasing portion of the age function cannot be due to physical and functional depreciation. Our theory suggests that the upwardly sloping portion of the age function is due to the option to redevelop or renovate older structures. ${ }^{32}$

As discussed in the theory section, intensity (here measured by the ratio of assessed building value to assessed land value, Intensity ${ }_{\text {Assessor }}$ ), should be inversely related to the amount of embedded option value in the hedonic regression. The second model in Table 6 adds $\ln \left(\right.$ Intensity $_{\text {Assessor }}$ ) and a dummy variable designed to capture missing values where Intensity Assessor $_{\text {is }}$ zero (Inten_Missing_BV). Intensity has the expected negative sign and it is statistically significant. The dummy variable works as expected to allow for a very large positive addition to value (nearly 99\%) when intensity is zero. ${ }^{33}$ A plausible interpretation of the four observations that show a $99 \%$ increase in value is that these represent irrevocable decisions to teardown: i.e., the teardowns considered by Rosenthal and Helsley (1994) and by Dye and McMillen (2007). The next biggest addition from option value is about $17.5 \%(9.3 \%)$ when intensity is equal to .007 (.065, the 1 percentile point).

The third regression in Table 6 is intended to test the idea that intensity will have a highly nonlinear effect, with most of the option value concentrated at smaller levels of intensity. I.e., the log of intensity is only an approximation to theoretical functional form,

\footnotetext{
${ }^{32}$ It is possible that "vintage effects" cause houses with better initial construction quality to experience increases in value. Such houses are often in neighborhoods with similarly well built structures, so the neighborhood may appreciate with age. Well built properties may be substantially renovated, but the "year built” reflects the original year of construction, a measurement problem.

${ }^{33}$ For the 4 observations with Intensity $_{\text {Assessor }}=0$, we plugged a value of -10 for $\ln \left(\right.$ Intensity $\left._{\text {Assessor }}\right)$ a smaller value than the -5 for the lowest nonzero value of intensity. We controlled for this substitution by setting Inten_Missing_BV $=10$ for these 4 observations, otherwise zero. The $99 \%$ is calculated as $\exp \left(-0.0324 *_{-}-10\right.$ $+0.0368 * 10)-1$.
} 
equation (11). The nonlinear effect of intensity is confirmed for the significant negative coefficient on the log of intensity up to its $25^{\text {th }}$ percentile point and the insignificance of the coefficient on $\ln \left(\right.$ Intensity Assessor $_{\text {: }}$ : below the $25^{\text {th }}$ percentile point the elasticity of price with respect to intensity is about $-5 \%$ whereas it is only $-3 \%$ in Model 2 . We tentatively conclude that much of the significant negative effect is concentrated in these low values for log of intensity.

The fourth model in Table 6 is the same as the third except that the log of intensity is interacted with the age variable in order to isolate option value effects from depreciation. This regression shows that the log of intensity significantly changes the slope of the age effect. We will show in Figure 2 and Table 8 that changes in the age effect are consistent with option value theory.

Model 5 in Table 6 interacts large lot size (a dummy for lots greater than 16,000 square feet) with the intensity variable. As predicted, large lots are associated with a significant increase in the effect of intensity. The increase is substantial: e.g., calculations show that property value decreases by $13.3 \%$ between the $10^{\text {th }}$ percentile and the $90^{\text {th }}$ percentile of intensity for large lots vs $7.6 \%$ for small lots for a 49 year old structure. ${ }^{34}$ This compares to a $9.2 \%$ change in value at the median age for model 4 , where the lot interaction is omitted. We conclude that lot size has an economically important effect on option value.

Table 7 replicates analysis in Table 6 using our second proxy for intensity: the ratio of interior square footage of subject property to the average interior square footage

\footnotetext{
${ }^{34}$ Note that the age of properties in Greenwich has the following distribution: $10^{\text {th }}$ percentile $=19$ years, median $=49$ years, $90^{\text {th }}$ percentile $=81$ years. The same calculations for $10^{\text {th }}$ percentile of age $\left(90^{\text {th }}\right.$ percentile) show the following decreases in prices: $7.0 \%$ (10.5\%) for large lots, $.9 \%(4.6 \%)$ for small lots (Table 6, Model 5), and 2.4\% (5.8\%) for Model 4 of Table 6, which omits lot interaction dummy.
} 
of nearby new construction (Intensity New Const). $^{35}$ It is reassuring that the results for all variables are qualitatively similar for both of these measures of intensity that are constructed in entirely different way. For example, comparing model 4, Table 6 with model 3, Table 7 shows that estimated age effects shift in the same way. This suggests that depreciation, controlling for option value can be estimated even in the absence of assessor data.

Figure 1 demonstrates economically important effects of intensity for model 4 in Table 6 and model 3 in Table 7. The highly nonlinear interaction between property value and intensity is illustrated by the percentile points for age in model 4 of Table 6 (see Figure 1.1). When building age is held constant at 81 years, value is reduced by $5.8 \%$ between the $10^{\text {th }}$ and $90^{\text {th }}$ percentile of intensity measured by the assessor, with most of the reduction concentrated over the lower $25^{\text {th }}$ percentile. I.e., the value of the option to redevelop an old, low intensity property is $5.8 \%$ (10.5\% for large lots, model 5$)$; this is close to the range estimated by Quigg (1993) for option value of empty lots using Seattle residential properties. The value to redevelop median property is only $1.8 \%$ in our sample (3.5\% for large lots and $1.1 \%$ for small lots). ${ }^{36}$ By way of contrast, intensity estimated

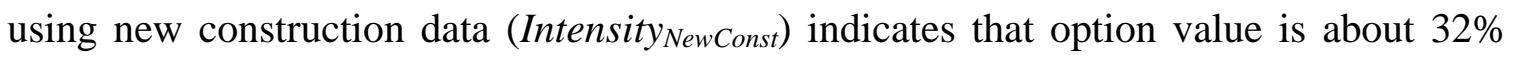

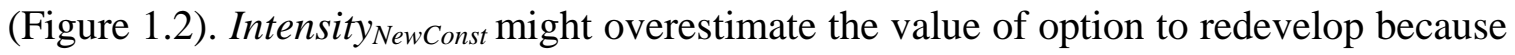
this measure does not account for the age, land value and other potential constraints to development, while Intensity Assessor $_{\text {does. }}$

\footnotetext{
${ }^{35}$ In results not shown we also used 0.75 mile buffer to identify new construction. All results are qualitatively similar. We report results using 1.25 mile buffer because we lose fewer observations (53 sales) when constraining number of newly constructed properties to be more than 3 (compared to 525 lost observations when using 0.75 mile buffer).

${ }^{36}$ This value is calculated as the difference in marginal effect on price between the 50th percentile and the 90th percentile of intensity at median age of 49 years using Table 6, Model 4 . The calculations for large and small lots are performed for Table 6, Model 5.
} 
While the marginal effect of Intensity $_{\text {NewConst }}$ is consistent with option theory, the relative positions of the lines for the $10^{\text {th }}$ and $90^{\text {th }}$ percentile of age indicate less option value for the older property, a finding not supported by the theory (Figure 1.2). However, the relative positions of the curves flip if we substitute median age for the $90^{\text {th }}$ percentile,

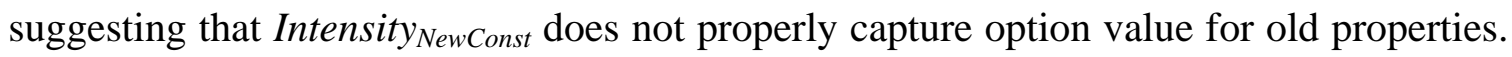
Therefore, we rely more heavily on results using intensity measured by the assessor.

Figure 2 provides analysis of the age variable holding constant for intensity: i.e., it uses the coefficients from model 4, Table 6 and model 3, Table 7 to graph the partial effect of age on predicted property value. When high option value is present (the $10^{\text {th }}$ percentile of Intensity Assessor $_{\text {, }}$, age is associated with no more than a $1.6 \%$ decline in property value over the first 20 years. This is consistent with theory, which indicates that depreciation loses relevance as option value increases. But when option value is low (the $90^{\text {th }}$ percentile of Intensity $_{\text {Assessor }}$ ) the decline in property value over 20 years is about 10.7\%. Age is associated with 7.5\% decline over the first 20 years in the hedonic model without intensity, suggesting that the age effect is underestimated by about 3.2 percentage points whereas the age effect for a property with a lot of redevelopment potential are overestimated by about 5.9 percentage points. For new high-intensity properties our model suggests that the rate of decline with respect to age is a more accurate measure of depreciation. Figure 2.2 supports this conclusion when intensity is measured with new construction. This is important because it suggests that a researcher armed with a standard hedonic dataset and our model can obtain a reasonable approximation to depreciation, provided that the data are geocoded. 
Table 8 evaluates annual age effects as the slopes of the lines in Figure 2: i.e., the derivatives with respect to age of the two regressions plotted. Our estimates of age effects in panel A suggest that the depreciation rate for 10 year old properties is about .6\% per year after controlling for the positive bias predicted by option value theory. The effect of omitting the intensity variable is economically important (upward bias in the age effect of about $.52 \%$ per year at 10 years of age) and statistically significant $(F=10.45) .{ }^{37}$ Our estimates of depreciation are about the same as those of Malpezzi, Ozanne, and Thibodeau (1987): their renter equations show an average age effect of about -.6\% per year for 59 metropolitan areas in the mid 1970's. ${ }^{38}$ Our 10 year old properties provide reasonable control for construction quality, and our model specification includes many location variables as well as land value. Therefore, we have responded to the three areas of concern identified by Malpezzi, Ozanne, and Thibodeau (1987).

Age effects estimated from Model 1, the standard hedonic are -.4\% (-.3\%) for 10 year old (19 year old) structures. When compared to the numbers for high intensity properties (-.6\% and $-.4 \%)$ this indicates that the standard hedonic regression substantially underestimates depreciation effects. ${ }^{39}$

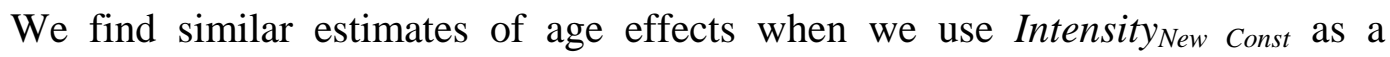
measure of intensity, Table 8, panel B. When option value is high, age is associated with no significant change in property value at age 10 years. The effect of age becomes

\footnotetext{
${ }^{37}$ The test is for the linear restriction that $(-3.46 \mathrm{E}-03) *(-1.263)+2 *(3.15 \mathrm{E}-05) *(-1.263) * 10=(-3.46 \mathrm{E}-03)$ $*(.563)+2 *(3.15 \mathrm{E}-05) *(.563) * 10$, where -1.263 is the $10^{\text {th }}$ percentile of $\ln \left(\right.$ Intensity $\left.{ }_{\text {Assessor }}\right)$ and 0.563 is the $90^{\text {th }}$ percentile. The test is performed for Model 4 of Table 6.

${ }^{38}$ Malpezzi, Ozanne, and Thibodeau (1987) owner equations show an average age effect of about -.4\% per year for 59 metropolitan areas. Our results suggest that this number is positively biased by the presence of option value.

${ }^{39}$ Not surprisingly, age effects estimated by the standard hedonic are nearly equal to those for the median intensity property. Note that the $-.4 \%$ is the same as the estimate from Malpezzi, Ozanne, and Thibodeau (1987) owner equations. It would be interesting to know if the substantial variation they found across metropolitan areas could be explained by including an intensity variable in their regressions.
} 
negative when option value is low and accounts for .58\% per year decline in property value at age 10 years. The difference in slopes at $10^{\text {th }}$ and $90^{\text {th }}$ percentile of intensity keeping age constant at 10 is significant at the $1 \%$ level $(\mathrm{F}=10.26)$.

Table 8 shows that the age effect becomes significantly positive by the median age of 49 years. A plausible explanation of this is that age is based on the year of construction, not the year of major renovation. Older properties in Greenwich are likely to have been renovated and the sample of older structures is selective because those with higher construction quality are more likely to survive. Thus, the vintage problem noted by Malpezzi, Ozanne, and Thibodeau (1987) dominates the results for older properties.

Equation (8) predicts downward bias in hedonic coefficient on interior square footage and an upward bias in hedonic coefficient on lot size when the option value term is ignored. Table 6 suggests that the bias in the implicit price of log of square footage (Footage) is about $-.024(=.666-.690)$ or roughly $3 \%$ of the value of the coefficient. Additional tests indicate that this is statistically significant, but its economic relevance is open to question. ${ }^{40}$ Similarly the results suggest small upward bias in the coefficient on $\log$ of lot size. These results are likely due to the small amount of overall option value in Greenwich, where only about $2 \%$ of sales were identified as teardowns by the assessor. As discussed above, model 4, Table 6 suggests $1.1 \%$ to $3.5 \%$ option value, holding age at its median of 49 years. If one were interested in predicting house value, we find that omitting the intensity variable biases the predicted log of house prices downward by $2.8 \%$ at the for $25^{\text {th }}$ percentile of intensity and by $4.8 \%$ for $10^{\text {th }}$ percentile of intensity. These differences are significant at the $10 \%$ level using a Wilcoxon rank-signs test.

\footnotetext{
40 To test statistical significance, we shifted the coefficient of $\ln$ (Footage) with a dummy for larger lots and older structures. We find that this dummy shifts the .66 coefficient upward by .011 (t-value=2.87).
} 
Hedonic pricing with redevelopment options

In general, econometric theory indicates that omitting the option variable will bias hedonic coefficients by greater amounts the larger the amount of option value present in the market. We have documented substantial bias in the age coefficients, but not other coefficients, when the median house has less than $2 \%$ option value for a house of median age. Preliminary results for housing in Berlin Germany during the 3 years following the fall of the Wall (1989-92) suggest that the standard hedonic coefficients on interior area and lot size can be biased in the expected direction by 20 to $30 \%$ in a market that has $10 \%$ to $15 \%$ of value in the option. ${ }^{41}$

\subsection{Robustness Tests}

Table 9 investigates our $3^{\text {rd }}$ measure of intensity, the proportion of teardowns ( $P_{\text {Teardown }}$ ) within 3/4 of a mile of each observation within 3 years of the sale. Theory says that option value will increase when a property is located in a neighborhood with a lot of redevelopment; i.e., in the presence of heightened land value relative to structure value. Note that the percent torn down has a highly nonlinear, option-like distribution (about $1 / 3^{\text {rd }}$ have zero values).

To construct a robust measure of the percent teardown, we eliminated 315 properties that did not have 10 or more neighboring sales within 0.75 miles to arrive at a sample of 4,557 properties. Land is cheaper in more remote locations, so the resulting sample has lower interior square footage and lot size (2,674 square feet, and 38,917 square feet, respectively). ${ }^{42}$ Mean year built, sale price and year of sale did not change

\footnotetext{
${ }^{41}$ Draft paper co-authored with Thies Lindenthal, available from the author on request.

${ }^{42}$ Table showing descriptive statistics for this sample is omitted and is available from the authors upon request.
} 
materially. ${ }^{43}$ The sample of 4,557 properties is closer to CBD, interstates and Long Island Sound. This is not surprising because the main difference between the two samples is the elimination of properties that did not have 10 or more neighboring sales within 0.75 miles. The eliminated properties are more likely to be located in more remote areas.

The first two models of Table 9 repeat the standard hedonic model and the best regression involving log of intensity, using the smaller dataset with information on teardowns. The results for these models are similar to those reported in Table 6, suggesting that smaller dataset did not induce any biases. The third model introduces the proportion of teardowns. As predicted by the theory of real options, the proportion of teardowns has a significant positive coefficient. ${ }^{44}$ The last two columns add intensity variables to the proportion of teardowns. The coefficient on the latter is remarkably stable to the addition of the other option variables. Moreover, the coefficients on the intensity variables are changed little by the addition of $P_{\text {Teardown }}$, supporting the robustness of the Intensity Assessor $_{\text {coefficients reported in Table } 6 .}$

Ten fold out-of-sample cross validation was used as an additional test for robustness. The sample of 5,218 sales was divided randomly into 10 nearly equal parts. One part was withheld and the models were estimated for the remaining 90\%. Estimated coefficients were used to predict the log of price for the withheld sample. The percentiles and mean of the absolute errors were calculated. Table 10 presents the mean results of repeating this process for all 10 parts of the data: e.g., the mean of the 10 median absolute percent errors is .1869 for the standard hedonic model.

\footnotetext{
${ }^{43}$ We plotted the distribution of sales by year for both the 5,218 and 4,557 samples (not shown). Both show a time pattern consistent with the real estate boom that occurred from 2000 - 2006.

${ }^{44}$ We tested for downward bias in the coefficient of $\ln$ (Footage) by using a dummy variable with values of one for properties with the proportion of teardowns greater than the median. This variable shifted the coefficient of $\ln$ (Footage) up by about $1.5 \%$ (t-value=3.8).
} 
The results show that the model 4 in Table 6 performed better than the standard hedonic at all percentile points except at the lowest $10^{\text {th }}$ percentile, the easiest prices to predict. The improvement in predictive accuracy is about one percent. Model 5 in Table 6 also outperformed the standard hedonic at most percentile points.

Ten fold cross validation was used to implement the grid search method for the best parameter $B_{1}$ : see discussion of equation (11). The grid search did converge to a value of -1.1 for the parameter. ${ }^{45}$ However, the predictive accuracy of equation (11) is not as good as equation (12) at most percentile points. Therefore, we present results from equation (12) in Tables 6 and 7.

Robustness of model specifications were tested with several interactions of intensity with the lot size dummy: an example is given by model 5, Table 7 . Coefficients on the remaining intensity variables are robust to this addition. Finally, our findings are robust when we clustered standard errors using neighborhoods defined as the seventeen Greenwich census tracts, so the 65 cell grid we used was not influential.

\subsection{Relationship to previous empirical studies of teardowns}

Most previous empirical studies are focused on discrete choice models of the decision to develop or redevelop. See Bulan, Mayer and Somerville (2009) for a recent summary and discussion of issues addressed and Cunningham (2007) for an empirical study based on Capozza and Li (1994). Most importantly for our purposes, Rosenthal and Helsley (1994) develop and test a valuation model of the decision to teardown. At the point of optimal demolition, the value of the existing property (structure plus land) is approximately equal to the value of the newly built property minus construction costs.

${ }^{45}$ Convergence was indicated by the U-shaped distribution of the median absolute error as a function of $B_{1}$. E.g., at -.9 the error was .1864 compared to .1858 at -1.1 and .1859 at -1.3 . 
The word "approximately" is inserted to allow for demolition costs which Rosenthal and Helsley find to be negligible. ${ }^{46}$ Thus, if the property is sold as a teardown we observe vacant land value which is equal to the expected net present value of the land with an optimally designed structure.

Comparing this model with equation (4) we see that the Rosenthal and Helsley model corresponds to the case where use value is approximately zero and option value is near $100 \%$ of property value. This is the case once an irrevocable decision has been made to tear down - perhaps indicated by binding contracts to demolish. But if a possibility of delay is present, and if a structure exists on the land, then the property is likely to have at least some use value.

Our measure of "teardowns” differs from those used by Rosenthal and Helsley (1994) and by Dye and McMillen (2007) as discussed above. When Rosenthal and Helsley field tested 40 of their teardowns they found that $90 \%$ had exercised, whereas we find that only 48\% had exercised in Greenwich. When Dye and McMillen implement a probit model that allows for classification error, the results suggest that little error was present in their data. But our data show that the ratio of sales price to assessed land value averages over $150 \%$ at the time of the "teardown" sale, so we conclude that substantial use value is present.

To summarize, our data indicate that the "teardown" classification is merely the assessor's judgment that the property has had or will have value as a teardown: i.e., the date at which the teardown occurs is not known. This opinion adds information to our intensity variable. On the other hand, our teardown indicator does not measure an

\footnotetext{
${ }^{46}$ Estimates produced by the Greenwich town assessor support this: the average demolition cost is $1.25 \%$ of sales price. However, the distribution of this percentage has a long right tail: the standard deviation is $5.6 \%$ and the maximum is over $90 \%$.
} 
Hedonic pricing with redevelopment options

irrevocable decision to demolish, so we cannot directly compare our results to those of Rosenthal and Helsley (1994) and Dye and McMillen (2007).

\section{Conclusions}

Hedonic characteristics of durable assets may contain an implicit characteristic, the embedded option to redevelop to a higher level. Option pricing theory suggests two additive terms: the use value term is the same as in standard hedonic theory, with the same expected coefficients. The second term in the valuation equation, a non-negative option term, is a decreasing function of the aggregate level of the existing vector of hedonic characteristics per unit land value: i.e., decreases in the intensity of the existing property.

This analysis implies that the standard hedonic model is mis-specified, but only in the presence of significant option value. In this case, theory shows that omitted variables bias is downward, so that implicit prices of positively valued characteristics will be underestimated in the absence of the option term. Option theory suggests that coefficients on building age will capture some of the option value: i.e., be biased upward in the absence of an option value term.

We test these implications of the model with data from Greenwich, Connecticut. Empirical results confirm the major implication of the theory: variables measuring the intensity of the existing vector of hedonic characteristics have the expected negative exponent. Moreover, a nonlinear model is capable of producing results that plausibly distinguish between option value and use value. The data support the prediction that the 
value of the option to redevelop is an important and statistically significant characteristic associated with durable assets.

Our data indicate that significant bias may be present in the coefficients on age variables which are typically viewed as measuring depreciation and obsolescence. With a properly specified option term, the negative effects of age are primarily associated with properties that have little option value. ${ }^{47}$ The presence of substantial option value (low levels of intensity) eliminates almost all the effects of building age. We conclude that coefficients on the age variable are biased upward by omission of the intensity variable even when relatively little option value is present in the market. ${ }^{48}$ On the other hand, the coefficients on the log of interior square footage are biased downward by statistically significant but economically small amounts.

\footnotetext{
${ }^{47}$ Our results using a new construction variable suggest that depreciation can be measured fairly accurately with a standard hedonic dataset, provided that the observations are geocoded.

${ }^{48}$ Our estimates at the median sale in Greenwich indicate that between $1.1 \%$ and $3.5 \%$ of median property value is due to option value, depending on lot size.
} 


\section{References}

Arguea, N.M., Hsiao, C., 1993. Econometric Issues of Estimating Hedonic Price Functions: With an Application to the U.S. Market for Automobiles. Journal of Econometrics 56, 243-67.

Boyarchenko, S., 2004. Irreversible Decisions and Record-Setting News Principles. American Economic Review 94, 557-68.

Bulan, L., Mayer C., Somerville, C. T., 2009. Irreversible Investment, Real Options, and Competition: Evidence from Real Estate Development, Journal of Urban Economics 65, 237-251.

Cameron, A.C., Gelbach J.B., Miller, D.L., 2008. Bootstrap -Based Improvements for Inference with Clustered Errors. Review of Economics and Statistics XC, 414427.

Capozza, D., Li, Y., 1994. The intensity and timing of investment: the case of land. The American Economic Review 84, 889-904.

Clapp, J.M., Carmelo, G., 1992. Estimating Price Trends for Residential Property: A Comparison of Repeat Sales and Assessed Value Methods, The Journal of Real Estate Finance and Economics 5, 357-74.

Clapp, J.M., Carmelo, G., 1998. Residential Hedonic Models: A Rational Expectations Approach to Age Effects. Journal of Urban Economics 44, 415-437.

Clapp, J.M, Jou, J., Lee, T., 2008. Buy to Scrape? Hedonic Pricing with redevelopment Options. Draft paper at http://papers.ssrn.com/sol3/papers.cfm?abstract_id=1048801 .

Coulson, E., McMillen, D., 2008. Simultaneous Estimation of Cohort, Age, and Time Effects in Housing Prices. Journal of Housing Economics 17, 138-151.

Cunningham, C.R., 2007. Growth Controls, Real Options and Land Development. Review of Economics and Statistics LXXXIX(2), 343-358.

Dixit, A., 1989. Entry and Exit Decisions under Uncertainty, The Journal of Political Economy 97, 620-638.

Dixit, A. K., and R. S. Pindyck 1994. Investment under Uncertainty. Princeton University Press, Princeton, N.J.

Dreyfus, M.K., Viscusi, W. K., 1995. Rates of Time Preference and Consumer Valuations of Automobile Safety and Fuel Efficiency. Journal of Law and Economics 38, 79-105. 
Dye, R.F., McMillen, D.P., 2007. Teardowns and Land Values in the Chicago Metropolitan Area. Journal of Urban Economics 61, 45-63.

Ekeland, I., Heckman, J.J., Nesheim, L. P., 2003. Identification and Estimation of Hedonic Models. National Bureau of Economic Research, Inc, NBER Working Papers: 9910.

Goodman, A.C., Thibodeau, T.G., 1995. Age-related heteroskedasticity in hedonic house price equations. Journal of Housing Research 6, 25-42.

Greene, W.H., 2003. Econometric Analysis, Fifth Edition. Upper Saddle River, NJ: Prentice Hall.

Gunnelin, A., Soderberg, B., 2003. Term Structures in the Office Rental Market in Stockholm. Journal of Real Estate Finance and Economics 26, 241-65.

Harding, J.H., Rosenthal S.S., Sirmans, C.F., 2003. Estimating Bargaining Power in the Market for Existing Homes. Review of Economics and Statistics, LXXXV(1), 178-188.

Malpezzi, S., Ozanne, L., Thibodeau, T.G., 1987. Microeconomic Estimates of Housing Depreciation. Land Economics 63, 372-385.

McDonald, R., Siegel, D., 1986. The Value of Waiting to Invest. The Quarterly Journal of Economics, 101, 707-728.

Poterba, J.L., 1984. Tax Subsidies to Owner Occupied Housing: An Asset Market Approach. The Quarterly Journal of Economics 99, 729-752.

Quigg, L., 1993. Empirical Testing of Real Option-Pricing Models. Journal of Finance 48, 621-40.

Rosen, S., 1974. Hedonic Prices and Implicit markets: Product Differentiation in Pure Competition. Journal of Political Economy 82, 34-55.

Rosenthal, S., Helsley, R., 1994. Redevelopment and the Urban Land Price Gradient, Journal of Urban Economics 35, 182-200.

Sick, G., 1990. Capital Budgeting with Real Options. Monograph Series in finance and Economics, Monograph 1989-3 New York, NY.

Wheaton, W. C., 1982. Urban Spatial Development with Durable but Replaceable Capital. Journal of Urban Economics 12, 53-67.

Williams, J.T., 1997. Redevelopment of Real Assets. Real Estate Economics 25 387-407. 


\section{Hedonic pricing with redevelopment options}

Figure 1: Impact of intensity on the predicted price of the property

This is the relationship between predicted price and intensity, holding all other variables constant. Figure 1.1 (1.2) shows the relationship for Model 4 of Table 6 (Model 3 of Table 7). The price index is calculated by setting the predicted value at $10^{\text {th }}$ percentile of intensity (0.283 for Figure 1.1 and 0.335 for Figure 1.2$)$ to 100 , then allowing intensity to increase in increments of .1 up to its $90^{\text {th }}$ percentile (1.76 for Figure 1.1 and 1.052 for Figure 1.2 ). Intensity is calculated as the ratio of assessed building value to assessed land value in Figure 1.1 and as the ratio of interior square footage to the average square footage of new construction sold within 3 years of the subject sale and located within 1.25 miles in Figure 1.2. The kinks in the figures occur at the $25^{\text {th }}$ percentiles, where the slopes flatten by .039 (Figure 1.1) and by .0094 (Figure 1.2). The kink results from the inclusion of the variable 25th pctl - Ln (Intensity) that equals the natural logarithm of Intensity if in the lower 25th percentile.

Figure 1.1: Intensity is calculated using assessor's data

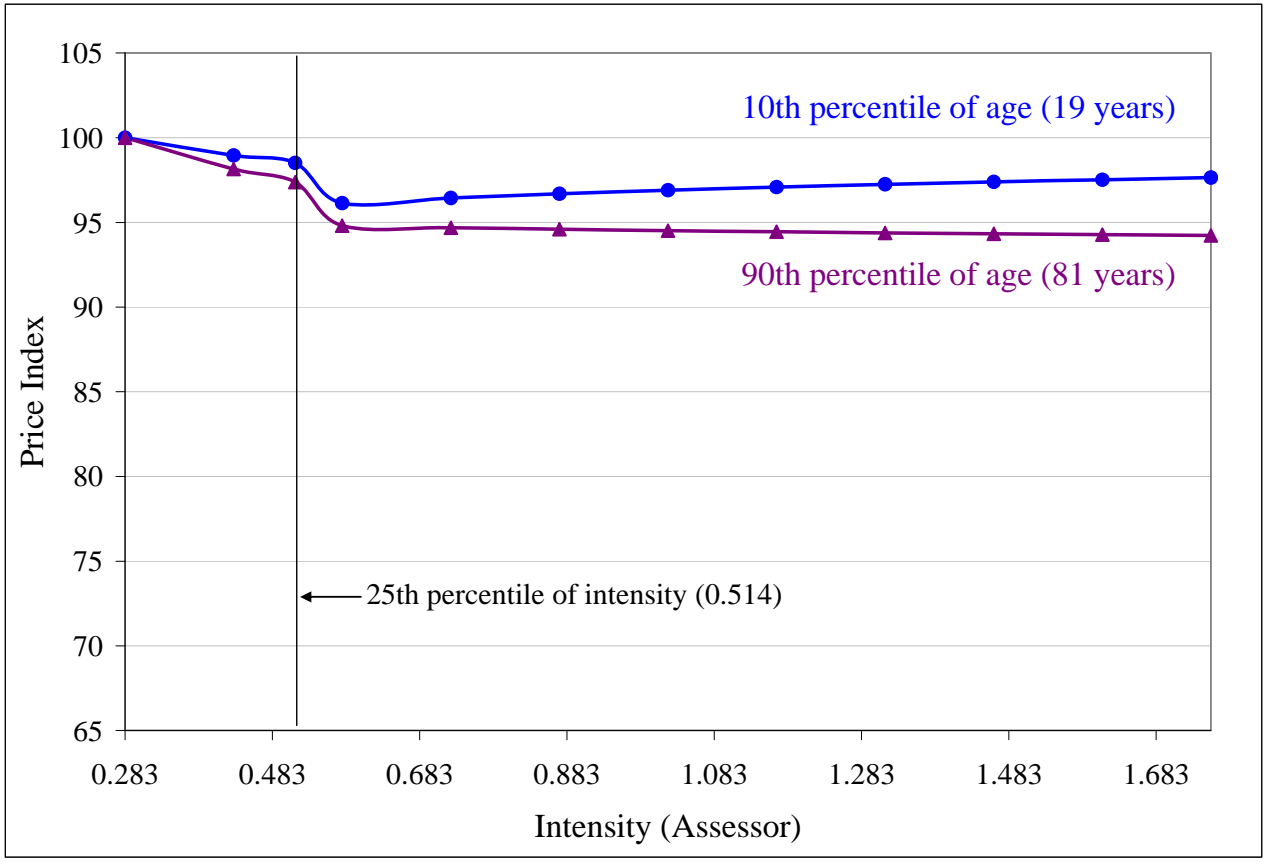

Figure 1.2: Intensity is calculated using new construction data

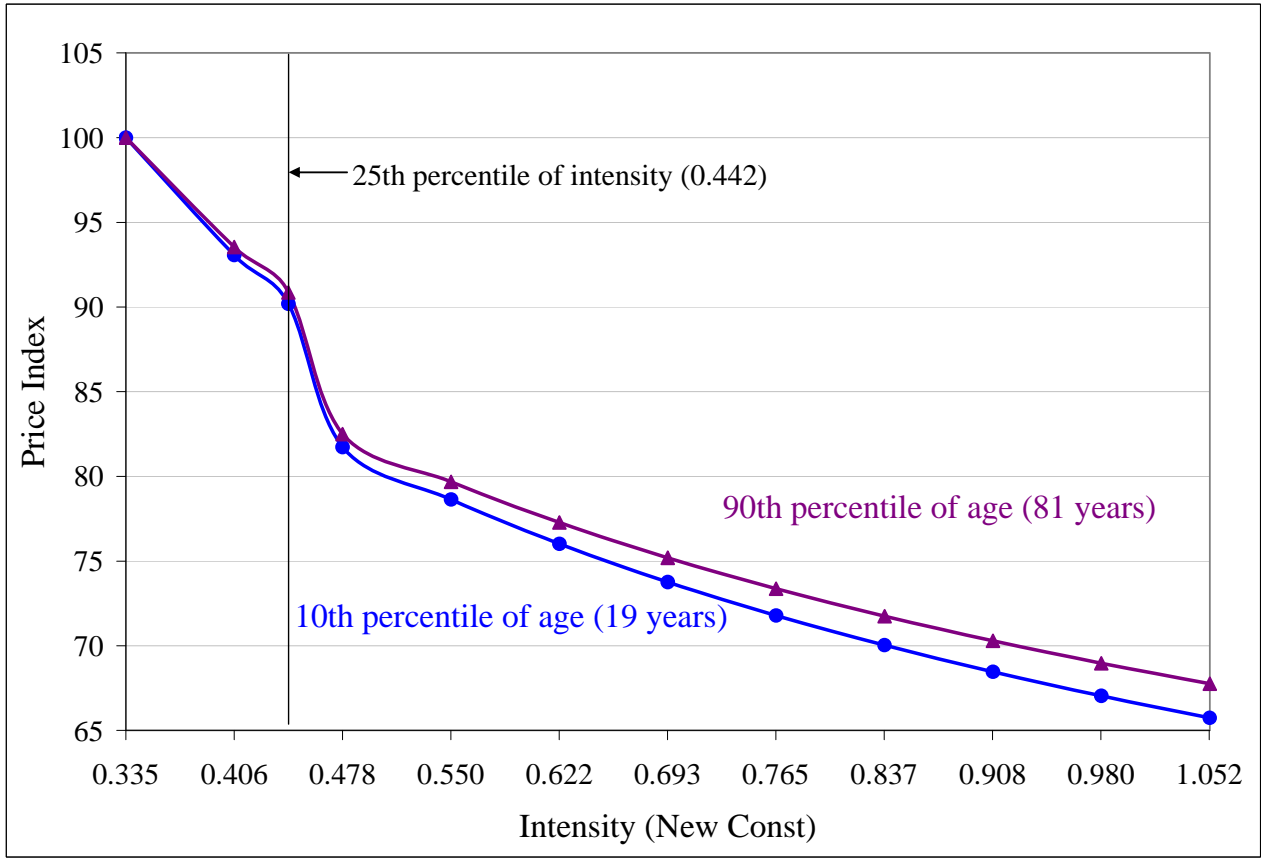




\section{Hedonic pricing with redevelopment options}

Figure 2: Impact of building age on predicted price

The figure shows the relation between predicted price and building age holding all other variables constant. Figure 2.1 (2.2) shows the relation for Model 4 of Table 6 (Model 3 of Table 7). The price index is constructed by setting the predicted value of price at age $=0$ to 70 and using $10^{\text {th }}$ and $90^{\text {th }}$ percentiles of the log of intensity $(-1.263$ and 0.564 , respectively for Figure 2.1; and -1.094 and 0.051, respectively for Figure 2.2). Intensity is calculated as the ratio of assessed building value to assessed land value in Figure 1.1 and as the ratio of interior square footage to the average square footage of new construction sold within 3 years of the subject sale and located within 1.25 miles from the property in Figure 1.2. The kink at the 25th pctl - Ln (Intensity) is one reason for the difference between the $10^{\text {th }}$ and $90^{\text {th }}$ percentile lines.

Figure 2.1: Controlling for Intensity calculated using assessor's data

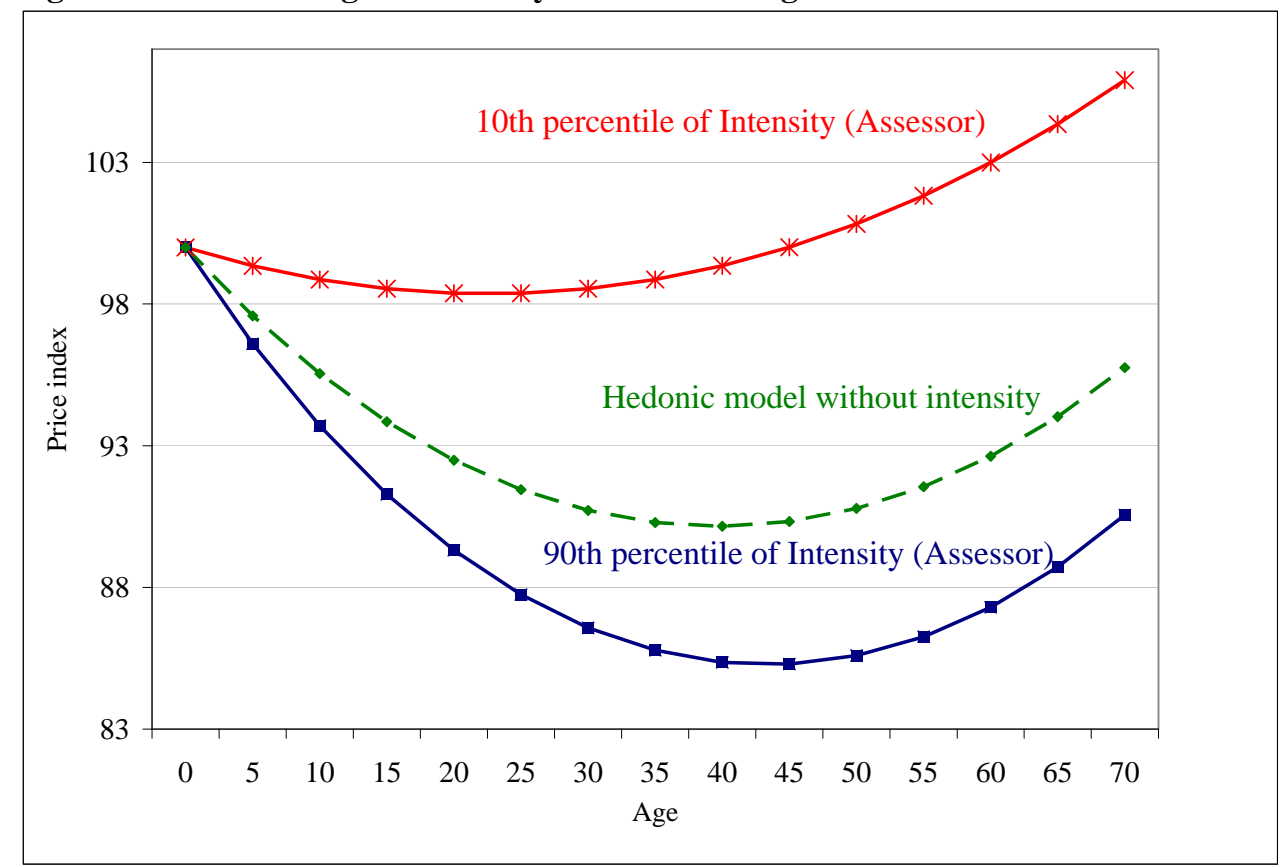

Figure 2.2: Controlling for Intensity calculated using new construction data

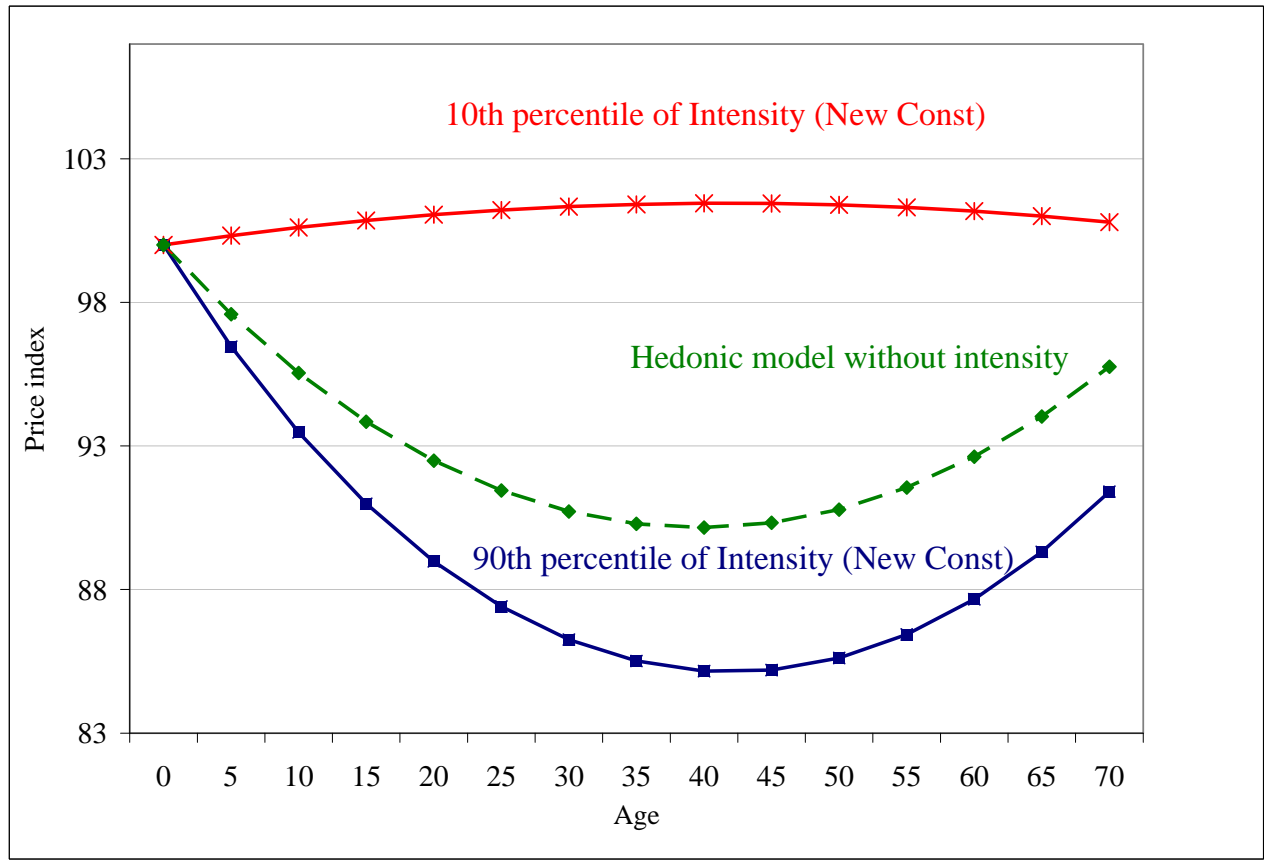




\section{Hedonic pricing with redevelopment options}

Table 1: Variable Definition

\begin{tabular}{|c|c|c|}
\hline Variable Name & Variable Description & Data Source \\
\hline 25th pctl - Ln (Intensity Assessor $_{\text {) }}$ & $\begin{array}{l}\text { Natural logarithm of Intensity }{ }_{\text {Assessor }} \text { if in the lower 25th percentile; } \\
\text { otherwise } 0 .\end{array}$ & Calculated \\
\hline 25th pctl - Ln (Intensity New Const $_{\text {) }}$ & $\begin{array}{l}\text { Natural logarithm of Intensity }{ }_{\text {New Const }} \text { if in the lower 25th percentile; } \\
\text { otherwise } 0 .\end{array}$ & Calculated \\
\hline \# of new buildings & $\begin{array}{l}\text { Number of new buildings (defined as Age }<16 \text { ) sold within } 3 \text { years and } \\
\text { within } 1.25 \text { miles of subject property. }\end{array}$ & $\begin{array}{l}\text { Calculated using } \\
\text { GIS and B\&T data }\end{array}$ \\
\hline Age & Age of the property in years (=Sale year - Year built). & B\&T \\
\hline $\mathrm{Age}^{2}$ & Age squared. & $\mathrm{B} \& \mathrm{~T}$ \\
\hline Baths2or3 & Equals one if the property has two or three bathrooms. & B\&T \\
\hline Baths3+ & Equals one if the property has more than three bathrooms. & B\&T \\
\hline Bedrooms4 & Equals one if the property has four bedrooms. & $\mathrm{B} \& \mathrm{~T}$ \\
\hline Beedrooms5+ & Equals one if the property has five or more bedrooms. & B\&T \\
\hline Dist_CosCob & $\begin{array}{l}\text { Distance in feet to Cos Cob harbor, a desirable and central location with } \\
\text { restaurants, shops and access to Long Island Sound. }\end{array}$ & GIS \\
\hline Dist_CosCob_D & Dummy for being within one mile of Cos Cob harbor. & GIS \\
\hline Dist_Interstate & Distance in feet to the nearest edge of an interstate. & GIS \\
\hline Dist_LISound & Distance in feet to nearest part of Long Island Sound. & GIS \\
\hline Footage & Interior square footage of the property at the time of sale. & $\mathrm{B} \& \mathrm{~T}$ \\
\hline Inten_Missing_BV & $\begin{array}{l}\text { Equals } 10 \text { when } \ln \text { (Intensity } \\
\text { ofsessor }) \text { is set to }-10 \text { because assessed value } \\
\text { of building }=0 \text {. }\end{array}$ & Calculated \\
\hline Intensity $_{\text {Assessor }}$ & Assessed value of the building divided by the assessed value of the lot. & $\begin{array}{l}\text { Calculated using } \\
\text { B\&T data }\end{array}$ \\
\hline Intensity ${ }_{\mathrm{New}}$ Const & $\begin{array}{l}\text { The ratio of interior square footage of subject property to the average } \\
\text { interior square footage of new construction located within } 1.25 \text { miles of } \\
\text { the subject property and sold within three years of the sale of the } \\
\text { subject property. }\end{array}$ & $\begin{array}{l}\text { Calculated using } \\
\text { B\&T and GIS data }\end{array}$ \\
\hline $\operatorname{Ln}(\ldots)$ & Natural logarithm. & \\
\hline Lot Size & Size of the property's lot in square feet. & B\&T \\
\hline Lot Large Dum & Equals one if lot size is above 16,000 sq. ft., otherwise zero. & Calculated \\
\hline Nuis_Interstate & $\begin{array}{l}\text { Nuisance for being too close to an interstate. Equals one if the distance } \\
\text { to the nearest edge of interstate in Greenwich is less than } 300 \\
\text { (Dist_Interstate<300). }\end{array}$ & GIS \\
\hline Nuis_RailRD & $\begin{array}{l}\text { Nuisance for being too close to the railroad. Equals one if the distance } \\
\text { in feet to the railroad is less than } 300 \text { feet. }\end{array}$ & GIS \\
\hline Price & Price at which the property was sold. & $\mathrm{B} \& \mathrm{~T}$ \\
\hline $\mathrm{P}_{\text {Teardown }}$ & $\begin{array}{l}\text { The percent of sales that have or had teardown potential within the } \\
\text { previous } 3 \text { years and within } 0.75 \text { miles of each observation. Teardown } \\
\text { sales are identified by the Greenwich town assessor; they are taken as a } \\
\text { percentage of B\&T sales. }\end{array}$ & $\begin{array}{l}\text { Calculated based } \\
\text { on Greenwich } \\
\text { assessor, B\&T and } \\
\text { GIS data. }\end{array}$ \\
\hline Sale year & Year the property was sold. & B\&T \\
\hline Sound view & $\begin{array}{l}\text { Positive externality for being close to Long Island Sound. Equals one if } \\
\text { distance to the nearest part of Long Island Sound is less than } 600 \text { feet } \\
\text { (Dist_LISound <600). }\end{array}$ & GIS \\
\hline Year built & Year the property was built. & $\mathrm{B} \& \mathrm{~T}$ \\
\hline
\end{tabular}


Table 2: Information collected by Greenwich assessor for all residential properties

Panel A: Land characteristics collected by Greenwich assessor

\begin{tabular}{ll}
\hline Land characteristic & Information recorded by assessor \\
\hline Land surface & Plated or non-plated \\
Plumbing system & Sewer or septic \\
Size & Front, back, right and left size \\
Topography & Level, rolling, swampy, or low. \\
Land type & Water frontage, rear lot, well, sidewalk, curb, gutter, \\
& Bellehaven (one of the most prestigious areas in Greenwich), \\
Land description & residential land, water frontage, primary commercial, etc \\
\hline
\end{tabular}

Panel B: Property characteristics collected by Greenwich assessor

\begin{tabular}{|c|c|}
\hline Property characteristic & Information recorded by assessor \\
\hline Building type & $\begin{array}{l}\text { Tudor, colonial, cape, ranch, raised ranch, contemporary, split } \\
\text { level, mansion, Victorian, cottage, Mediterranean. }\end{array}$ \\
\hline Condition of the property & $\begin{array}{l}\text { Very good for age, above normal for age, normal for age, below } \\
\text { normal for age, poor for age. }\end{array}$ \\
\hline Construction foundation & $\begin{array}{l}\text { Wood frame, stone, brick, stucco, vinyl, concrete block, aluminum, } \\
\text { steel, etc. }\end{array}$ \\
\hline Exterior & $\begin{array}{l}\text { Wood siding, vinyl siding, brick, stucco, alum siding, composition } \\
\text { siding, stone, etc. }\end{array}$ \\
\hline Roof shape & Gable, flat, shed, etc. \\
\hline Roof material & Asphalt shingles, slate or tile, wood shingles, etc. \\
\hline Attic & $\begin{array}{l}\text { Partial or none. Assessor also records square footage of attic when } \\
\text { there exists partial attic. }\end{array}$ \\
\hline Heating & $\begin{array}{l}\text { Hot water - gas, forced hot air-gas, hot water - oil, forced hot air- } \\
\text { oil, central warm air, electric baseboard, steam - gas, forced hot } \\
\text { air-elec, heat pump, steam - oil, electric radiant, hot water, etc. }\end{array}$ \\
\hline Cooling & Central air or window unit. \\
\hline Basement & Square footage of total basement area and finished basement area. \\
\hline Garage & $\begin{array}{l}\text { Indicator whether garage is attached or detaches; square footage of } \\
\text { garage. }\end{array}$ \\
\hline Deck & Square footage of the deck. \\
\hline Structures on the property & $\begin{array}{l}\text { Indicator of wether the property has any of the following structures: } \\
\text { pool, hot tub, bath house, fountain, fence, barn (traditional flat or } \\
\text { loft), barbecue, green house, bulkhead wall. }\end{array}$ \\
\hline Fireplaces & Fireplace stacks and openings and additional fireplace openings. \\
\hline Permits for improvements & $\begin{array}{l}\text { Includes detailed description of improvement. For example, } \\
\text { detailed description of interior or exterior work: installation of air } \\
\text { conditioning, swimming pool, expansion of kitchen and family } \\
\text { room, installation of new appliances, renovation of bathroom and } \\
\text { kitchen area, replacement of switches and plugs, removal of } \\
\text { existing garage and its replacement with new master bedroom and } \\
\text { master bath. }\end{array}$ \\
\hline
\end{tabular}


Table 3: Data Filters for Full Sample of Properties

The sample includes single family residential properties sold between 1995 and 2007 in Greenwich, Connecticut. Price is the price at which the property was sold. Footage is the interior square footage of the property. Lot size is the size of the property's lot in square feet. Year built is the year the property was built. Sale year is the year the property was sold. We test statistical significance of the difference in means for Price, Footage and Lot size using a ttest. ***, **, * indicate significance at $1 \%, 5 \%$ and $10 \%$, respectively. Changes in means of Year built and Sale year are not tested because these variables do not follow a t-distribution and the changes are too small to justify a nonparametric test.

\section{Panel A: Summary statistics for selected variables for sample that plots within Greenwich boundaries}

Single family residential properties with warranty deeds that plot within Greenwich boundary

\begin{tabular}{|l|l|r|r|r|r|}
\hline Variable Name & $\begin{array}{c}\text { Number } \\
\text { of obs }\end{array}$ & \multicolumn{1}{c|}{ Mean } & \multicolumn{1}{c|}{ Std. Dev. } & \multicolumn{1}{c|}{ Min } & \multicolumn{1}{c|}{ Max } \\
\hline Price & 5,871 & $\$ 1,662,543$ & $\$ 1,876,563$ & $\$ 4,000.00$ & $\$ 63,100,000.00$ \\
\hline Footage & 5,871 & 2,792 & 1,741 & 0 & 19,096 \\
\hline Lot size & 5,871 & 47,031 & 69,893 & 0 & 818,928 \\
\hline Year built & 5,861 & 1946 & 34 & 1189 & 2006 \\
\hline Sale year & 5,871 & 2002 & 4 & 1994 & 2007 \\
\hline
\end{tabular}

Panel B: Summary statistics for selected variables for sample that plots within Greenwich boundaries after applying data filters.

Price $<\$ 50,000$ less:

Footage $<300$ less:

Lot Size $<1500$ less:

Total number of rooms $<3$ less:

Resulting sample for OLS regression:
Number of bathrooms $<0.50$ less:

Year built $<1900$ less:

Year built $>2007$ less:

Land assessed value is missing less:
55

467

2

12

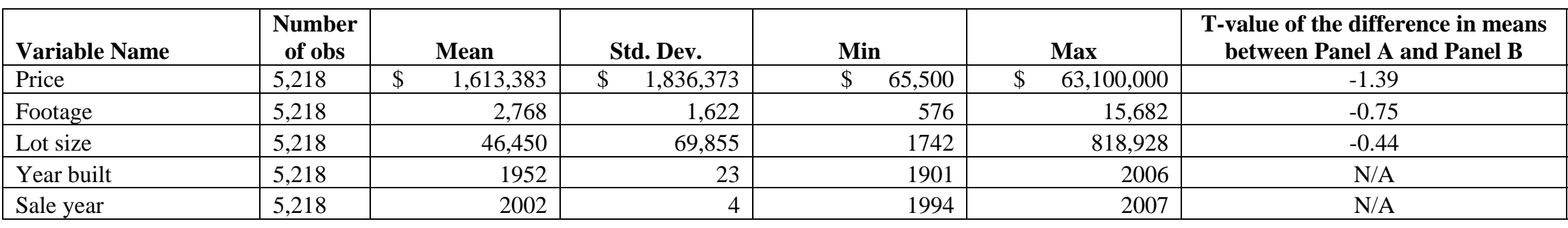


Table 4: Descriptive Statistics for Sample of 5,218 properties

The sample includes single family residential properties sold between 1995 and 2007 in Greenwich, Connecticut. Price is the price at which the property was sold. $L$ (Price) is the natural logarithm of the price. Dist_CosCob is the distance to Cos Cob harbor. Dist_LISound is the distance to nearest part of Long Island Sound. Dist_Interstate is the distance to the nearest edge of interstate. All distances are in feet. Footage is the interior square footage of the property. Lot size is the size of the

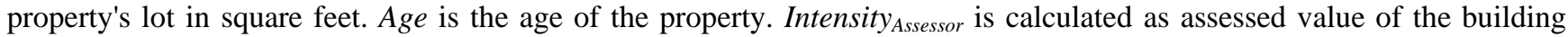
divided by the assessed value of the lot. Intensity ${ }_{\text {New }}$ Const is the ratio of interior square footage of subject property to the average interior square footage of new construction located within 1.25 miles of the subject property and sold within three years of the sale of the subject property. $\operatorname{Ln}($.$) is the natural logarithm. Inten_Missing_BV equals 10$ when In (Intensity Assessor $_{\text {) }}$ is set to -10 because assessed value of the building $=0.25^{\text {th }}$ pctl $-\operatorname{Ln}$ (Intensity Assessor $_{\text {) }}$ ) is the lower 25th percentile of variable Intensity $_{\text {Assessor }}$, otherwise zero. $25^{\text {th }}$ pctl - Ln (Intensity New Const $_{\text {) }}$ is the lower 25th percentile of variable Intensity New Const $_{\text {, }}$ otherwise zero. $P_{\text {Teardown }}$ is the percent of sales that have or had teardown potential within 3 years and within 0.75 miles of each observation. Teardown sales are identified by the Greenwich town assessor; they are taken as a percentage of B\&T sales. Dist_CosCob_D is a dummy for being within one mile of Cos Cob harbor. Nuis_RailRD is a dummy for the nuisance for being too close to the railroad. Sound view is a dummy for the positive externality for being close to Long Island Sound. Nuis_Interstate is the nuisance for being too close to an interstate. Baths2or3 equals one if the property has two or three bathrooms. Bath3+ equals one if the property has more than three bathrooms. Bedrooms4 equals one if the property has four bedrooms. Bedrooms5+ equals one if the property has five or more bedrooms. Lot Large Dum is one if the lot is over 16,000 square feet.

Panel A: Continuous variables

\begin{tabular}{|c|c|c|c|c|c|}
\hline Variable name & Number of obs & Mean & Std. Dev. & Min & Max \\
\hline Price & 5,218 & $\$ 1,613,383$ & $\$ 1,836,373$ & $\$ 65,500$ & $\$ 63,100,000$ \\
\hline Ln (Price) & 5,218 & 13.94 & 0.81 & 11.09 & 17.96 \\
\hline Dist_CosCob & 5,218 & 17,716 & 12,238 & 435 & 58,709 \\
\hline Dist_LISound & 5,218 & 2,220 & 2,441 & 0 & 12,079 \\
\hline Dist_Interstate & 5,218 & 1,422 & 937 & 0 & 4,407 \\
\hline Footage & 5,218 & 2,768 & 1,622 & 576 & 15,682 \\
\hline Lot size & 5,218 & 46,450 & 69,855 & 1,742 & 818,928 \\
\hline Age & 5,218 & 50.43 & 22.93 & 0 & 105 \\
\hline Intensity ${ }_{\text {Assessor }}$ & 5,218 & 0.988 & 0.763 & 0.000 & 11.281 \\
\hline Intensity $_{\mathrm{New}}$ Const & 5,165 & 0.654 & 0.309 & 0.104 & 3.467 \\
\hline Ln (Intensity Assessor $_{\text {) }}$ ) & 5,218 & -0.277 & 0.819 & -10.000 & 2.423 \\
\hline Ln (Intensity ${ }_{\text {New Const }}$ ) & 5,165 & -0.525 & 0.445 & -2.259 & 1.243 \\
\hline Inten_Missing_BV & 5,218 & 0.008 & 0.277 & 0.000 & 10.000 \\
\hline $25^{\text {th }}$ pctl - Ln (Intensity $\left.{ }_{\text {Assessor }}\right)$ & 5,218 & -0.332 & 0.690 & -10.000 & 0.000 \\
\hline $25^{\text {th }}$ pctl - Ln (Intensity $\left.{ }_{\text {New Const }}\right)$ & 5,165 & -0.272 & 0.484 & -2.259 & 0.000 \\
\hline \# of new buildings & 5,218 & 24 & 14 & 0 & 74 \\
\hline $\begin{array}{l}\text { Ln (Intensity } \text { Assessor }) * \text { Lot Large } \\
\text { Dum }\end{array}$ & 5,218 & -0.134 & 0.623 & -10.000 & 2.423 \\
\hline $\mathrm{P}_{\text {Teardown }}$ & 4,557 & 0.035 & 0.040 & 0 & 0.400 \\
\hline
\end{tabular}

Panel B: Indicator variables

\begin{tabular}{|l|c|c|c|}
\hline Variable name & Number of obs & $\begin{array}{c}\text { Number of observations } \\
\text { where variable = 1 }\end{array}$ & $\begin{array}{c}\text { Number of observations where } \\
\text { variable = 1 (as a \%) }\end{array}$ \\
\hline Dist_CosCob_D & 5,218 & 790 & $15.14 \%$ \\
\hline Nuis_RailRD & 5,218 & 509 & $9.75 \%$ \\
\hline Sound view & 5,218 & 1,396 & $26.75 \%$ \\
\hline Nuis_Interstate & 5,218 & 622 & $11.92 \%$ \\
\hline Baths2or3 & 5,218 & 3,069 & $58.82 \%$ \\
\hline Baths3+ & 5,218 & 1,518 & $29.09 \%$ \\
\hline Bedrooms4 & 5,218 & 2,987 & $57.24 \%$ \\
\hline Bedrooms5+ & 5,218 & 1,187 & $22.75 \%$ \\
\hline Lot Large Dum & 5,218 & 2,676 & $51.28 \%$ \\
\hline
\end{tabular}




\section{Table 5: Data Filters for Properties with Teardown Potential}

Teardowns of single family residential properties were identified by the assessor of Greenwich, Connecticut for the years 1996-2007. See Table 1 and legend to Table 4 for variable definitions. Statistical significance of the difference in means for Price, Footage and Lot size as tested using a t-test. ***, **, * indicate significance at $1 \%, 5 \%$ and $10 \%$, respectively. Changes in means of Year built and Sale year are not tested because these variables do not follow a t-distribution and the changes are too small to justify a nonparametric test.

Panel A: Summary statistics for selected variables for of properties with teardown potential that plot within Greenwich boundaries

Single family residential properties with warranty deeds that plot within Greenwich boundary

\begin{tabular}{|l|l|r|r|r|r|}
\hline Single family residential properties with warranty deeds that plot within Greenwich boundary & \multicolumn{1}{c|}{219} \\
Variable name & $\begin{array}{c}\text { Number } \\
\text { of obs }\end{array}$ & \multicolumn{1}{c|}{ Mean } & Std. Dev. & \multicolumn{1}{c|}{ Min } & \multicolumn{1}{c|}{ Max } \\
\hline Price & 219 & $\$ 1,657,623$ & $\$ 1,064,699$ & $\$ 175,000$ & $\$ 8,000,000$ \\
\hline Footage & 219 & 2,492 & 1,272 & 766 & 9,270 \\
\hline Lot size & 219 & 60,325 & 75,994 & 0 & 773,190 \\
\hline Year built & 219 & 1947 & 26 & 1836 & 2001 \\
\hline Sale year & 219 & 2003 & 3 & 1996 & 2007 \\
\hline
\end{tabular}

Panel B: Summary statistics for selected variables for properties with teardown potential that plots within Greenwich boundaries after applying data filters.

Price $<\$ 50,000$ less:

Footage $<300$ less:

Lot size $<1500$ less:

Total number of rooms $<3$ less:

Number of bathrooms $<0.50$ less: $\quad 1$

Year built $<1900$ less: $\quad 19$

Year built $>2007$ less: $\quad 0$

Resulting sample for OLS regression:* 197

\begin{tabular}{|c|c|c|c|c|c|c|}
\hline 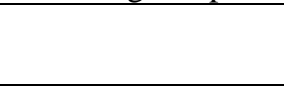 & \begin{tabular}{|c|c|}
$\begin{array}{c}\text { Number } \\
\text { of obs }\end{array}$ \\
\end{tabular} & Mean & Std. Dev. & Min & Max & $\begin{array}{c}\text { T-value of the difference in means } \\
\text { Panel A and Table } 3 \text { Panel B }\end{array}$ \\
\hline Price & 197 & $\$ 1,627,238$ & $\$ 1,016,661$ & $\$ 185,000$ & $\$ 8,000,000$ & -0.30 \\
\hline Footage & 197 & 2,527 & 1,276 & 770 & 9,270 & -0.28 \\
\hline Lotsize & 197 & 61,448 & 77,999 & 5,227 & 773,190 & 0.15 \\
\hline Yearbuilt & 197 & 1953 & 16 & 1902 & 2001 & N/A \\
\hline Saleyear & 197 & 2003 & 3 & 1996 & 2007 & N/A \\
\hline Intensity $_{\text {Assessor }}$ & 197 & 0.764 & 1.017 & 0.035 & 6.654 & N/A \\
\hline
\end{tabular}




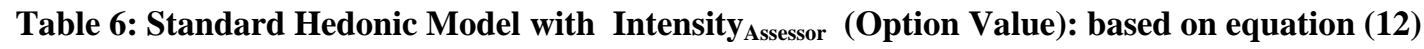

The sample includes single family residential properties sold between 1995 and 2007 in Greenwich, Connecticut. Dependent variable is

Ln(Price).Explanatory variables are described in Tables 1 and the legend to Table 4 . Standard errors where adjusted for spatial dependence by clustering into 65 grid squares. Robust t-statistics using Huber-White methods and spatial clustering are shown next to estimates of coefficients. ***, **, * indicate

significance at $1 \%, 5 \%$ and $10 \%$, respectively. We present t-values rather than standard errors because of our assumption that the market clears in terms of In(Price) rather than Price. For those who want to think in terms of levels it will be necessary to calculate confidence intervals and take exponents for the end points. For example the exponentiated end points for the important age variable, Model 1 are [.991 .998] and for age ${ }^{2}$ they are [1.000 1.000].

\begin{tabular}{|c|c|c|c|c|c|c|c|c|c|c|}
\hline \multirow[b]{2}{*}{ Variable } & \multicolumn{2}{|c|}{ Model 1} & \multicolumn{2}{|c|}{ Model 2} & \multicolumn{2}{|c|}{ Model 3} & \multicolumn{2}{|c|}{ Model 4} & \multicolumn{2}{|c|}{ Model 5} \\
\hline & $\begin{array}{l}\text { Estimated } \\
\text { Coefficient }\end{array}$ & $\begin{array}{c}\text { Robust } \\
\text { T-statistic }\end{array}$ & $\begin{array}{c}\text { Estimated } \\
\text { Coefficient }\end{array}$ & $\begin{array}{c}\text { Robust } \\
\text { T-statistic }\end{array}$ & $\begin{array}{l}\text { Estimated } \\
\text { Coefficient }\end{array}$ & $\begin{array}{c}\text { Robust } \\
\text { T-statistic }\end{array}$ & $\begin{array}{l}\text { Estimated } \\
\text { Coefficient }\end{array}$ & $\begin{array}{c}\text { Robust } \\
\text { T-statistic }\end{array}$ & $\begin{array}{l}\text { Estimated } \\
\text { Coefficient }\end{array}$ & $\begin{array}{c}\text { Robust } \\
\text { T-statistic }\end{array}$ \\
\hline Dist_CosCob & $-7.52 \mathrm{E}-06$ & $-2.59 * \star \star$ & $-7.30 \mathrm{E}-06$ & -2.51 ** & $-7.32 \mathrm{E}-06$ & -2.52 ** & $-7.24 \mathrm{E}-06$ & $-2.49 * \star$ & -7.29E-06 & $-2.51 * \star$ \\
\hline Dist_CosCob_D & $1.58 \mathrm{E}-01$ & $3.06 * * *$ & $1.58 \mathrm{E}-01$ & $3.09 * * *$ & $1.57 \mathrm{E}-01$ & $3.08 * * *$ & 1.57E-01 & $3.08 * * *$ & $1.59 \mathrm{E}-01$ & $3.10 * * *$ \\
\hline Nuis_RailRD & $-6.56 E-02$ & -1.96 * & $-6.52 E-02$ & -1.97 * & $-6.42 E-02$ & -1.93 * & $-6.42 E-02$ & -1.93 * & $-6.51 \mathrm{E}-02$ & -1.98 * \\
\hline Dist_LISound & $-9.41 E-07$ & -0.08 & $-9.15 E-07$ & -0.08 & $-7.44 \mathrm{E}-07$ & -0.06 & $-1.33 E-06$ & -0.11 & $-1.13 E-06$ & -0.09 \\
\hline Sound view & 8.12E-02 & $2.1 * *$ & 7.97E-02 & $2.07 * *$ & 7.81E-02 & 2.03 ** & 7.86E-02 & 2.06 ** & 7.83E-02 & 2.04 ** \\
\hline Dist_Interstate & $3.68 \mathrm{E}-05$ & 1.67 * & $3.60 \mathrm{E}-05$ & 1.66 * & $3.74 \mathrm{E}-05$ & 1.72 * & $3.72 \mathrm{E}-05$ & 1.72 * & $3.70 \mathrm{E}-05$ & 1.72 * \\
\hline Nuis_Interstate & $1.69 \mathrm{E}-02$ & 0.41 & $1.20 \mathrm{E}-02$ & 0.30 & $1.58 \mathrm{E}-02$ & 0.39 & $1.45 \mathrm{E}-02$ & 0.36 & 1.35E-02 & 0.33 \\
\hline Ln (Footage) & $6.66 \mathrm{E}-01$ & $23.49 * \star *$ & 6.89E-01 & $22.13 * * *$ & 6.91E-01 & 22.34 *** & 6.91E-01 & 22.54 *** & 6.90E-01 & $22.38 * \star \star$ \\
\hline Ln (Lot size) & 2.69E-01 & $13.13 * \star \star$ & 2.59E-01 & $12.56 * * *$ & $2.56 \mathrm{E}-01$ & $12.67 * \star \star$ & $2.56 \mathrm{E}-01$ & $12.70 * * *$ & $2.56 \mathrm{E}-01$ & $12.05 * \star *$ \\
\hline Baths2or3 & $-1.51 \mathrm{E}-03$ & -0.1 & 3.62E-04 & 0.02 & $-2.95 \mathrm{E}-04$ & -0.02 & $1.01 \mathrm{E}-03$ & 0.06 & $1.36 \mathrm{E}-03$ & 0.09 \\
\hline Baths3+ & 7.44E-02 & $2.71 * \star \star$ & 7.67E-02 & $2.72 * \star \star$ & 7.81E-02 & $2.77 * \star \star$ & 8.05E-02 & 2.84 *** & 8.20E-02 & $2.87 * * \star$ \\
\hline Bedrooms4 & $-1.39 E-02$ & -0.93 & $-1.33 E-02$ & -0.92 & $-1.23 \mathrm{E}-02$ & -0.87 & $-1.04 \mathrm{E}-02$ & -0.73 & $-1.08 \mathrm{E}-02$ & -0.76 \\
\hline Bedrooms5+ & 5.71E-02 & $2.89 * \star \star$ & 5.89E-02 & $3.03 * * *$ & $5.86 \mathrm{E}-02$ & $3.02 * * *$ & 5.75E-02 & $3.00 * * \star$ & 5.85E-02 & $3.03 * \star \star$ \\
\hline Age & $-5.22 \mathrm{E}-03$ & $-3.04 * * \star$ & $-5.73 E-03$ & -3.31 *** & $-5.51 E-03$ & -3.24 *** & $-5.85 E-03$ & $-3.34 * \star \star$ & $-5.82 E-03$ & -3.36 *** \\
\hline $\mathrm{Age}^{2}$ & 6.57E-05 & $4.18 * \star *$ & 7.01E-05 & 4.41 *** & 6.83E-05 & $4.38 * * *$ & 7.25E-05 & $4.45 * \star *$ & $7.21 \mathrm{E}-05$ & $4.50 * \star \star$ \\
\hline Constant & $5.46 \mathrm{E}+00$ & $31.05 * \star *$ & $5.39 \mathrm{E}+00$ & 29.06 *** & $5.39 \mathrm{E}+00$ & $28.94 * \star *$ & $5.39 E+00$ & 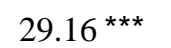 & $5.40 \mathrm{E}+00$ & $29.06 * * *$ \\
\hline Year dummies & yes & & yes & & yes & & yes & & yes & \\
\hline Ln (Intensity Assessor ) & & & $-3.24 \mathrm{E}-02$ & $-2.78 * \star \star$ & $-6.12 E-04$ & -0.04 & 6.84E-02 & $2.30 * *$ & 7.48E-02 & $2.59 * \star \star$ \\
\hline $\begin{array}{l}\text { Inten_Missing_BV } \\
25^{\text {th }} \text { pctl - }\end{array}$ & & & 3.68E-02 & 1.22 & 2.04E-02 & 0.67 & 2.30E-02 & 1.24 & 2.26E-02 & 1.23 \\
\hline Ln (Intensity Assessor $)$ & & & & & $-4.90 \mathrm{E}-02$ & $-2.60 * * *$ & $-3.91 E-02$ & $-2.07 * *$ & $-4.08 \mathrm{E}-02$ & $-2.18 * *$ \\
\hline Age* $^{*} \operatorname{Ln}\left(\right.$ Inten $\left._{\text {Assessor }}\right)$ & & & & & & & $-3.46 \mathrm{E}-03$ & $-2.89 * \star \star$ & $-3.27 \mathrm{E}-03$ & $-2.77 * \star \star$ \\
\hline Age $^{2 *} \operatorname{Ln}\left(\right.$ Inten $\left._{\text {Assessor }}\right)$ & & & & & & & 3.15E-05 & $2.61 * * \star$ & 2.93E-05 & $2.42 * \star$ \\
\hline Lot Large Dum* & & & & & & & & & & \\
\hline Ln(Intensity Assessor $_{\text {) }}$ & & & & & & & & & $-3.48 E-02$ & $-2.09 * *$ \\
\hline Lot Large Dum & & & & & & & & & $-8.34 \mathrm{E}-03$ & -0.43 \\
\hline Number of obs & 5218 & & 5218 & & 5218 & & 5218 & & 5218 & \\
\hline R-squared & $75.59 \%$ & & $75.69 \%$ & & $75.73 \%$ & & $75.78 \%$ & & $75.81 \%$ & \\
\hline
\end{tabular}


Table 7: Standard Hedonic Model with Intensity ${ }_{\text {New }}$ Const $($ Option Value) : based on equation (12)

The sample includes single family residential properties sold between 1995 and 2007 in Greenwich, Connecticut. Dependent variable is Ln(Price).Tables 1 and legend to Table 4. Standard errors where adjusted for spatial dependence by clustering into 65 grid squares. Robust tstatistics using Huber-White methods and spatial clustering are shown next to estimates of coefficients. ***,**, * indicate significance at $1 \%$, $5 \%$ and $10 \%$, respectively.

\begin{tabular}{|c|c|c|c|c|c|c|c|c|c|}
\hline \multirow{3}{*}{$\begin{array}{l}\text { Variable } \\
\text { Dist_CosCob }\end{array}$} & \multicolumn{3}{|c|}{ Model 1} & \multicolumn{3}{|c|}{ Model 2} & \multicolumn{3}{|c|}{ Model 3} \\
\hline & \multirow{2}{*}{$\begin{array}{c}\text { Estimated } \\
\text { Coefficient }\end{array}$} & \multicolumn{2}{|c|}{$\begin{array}{c}\text { Robust T- } \\
\text { statistic }\end{array}$} & \multirow{2}{*}{$\begin{array}{c}\begin{array}{c}\text { Estimated } \\
\text { Coefficient }\end{array} \\
-1.15 E-05\end{array}$} & \multicolumn{2}{|c|}{$\begin{array}{c}\text { Robust T- } \\
\text { statistic }\end{array}$} & \multirow{2}{*}{$\begin{array}{c}\text { Estimated } \\
\text { Coefficient }\end{array}$} & \multicolumn{2}{|c|}{$\begin{array}{c}\text { Robust T- } \\
\text { statistic }\end{array}$} \\
\hline & & -4.35 & 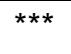 & & -4.57 & $* \star \star$ & & -4.55 & $\star \star \star *$ \\
\hline Dist_CosCob_D & $1.91 \mathrm{E}-01$ & 3.49 & $\star \star \star$ & 1.83E-01 & 3.40 & $\star \star \star$ & 1.83E-01 & 3.37 & $\star \star \star$ \\
\hline Nuis_RailRD & $-8.60 \mathrm{E}-02$ & -2.37 & $\star \star$ & $-8.38 E-02$ & -2.24 & $\star \star$ & $-8.00 \mathrm{E}-02$ & -2.15 & $\star \star$ \\
\hline Dist_LISound & $-5.40 \mathrm{E}-06$ & -0.5 & & -1.70E-06 & -0.16 & & $-2.10 \mathrm{E}-06$ & -0.20 & \\
\hline Sound view & 7.65E-02 & 1.89 & * & 7.32E-02 & 1.84 & * & 7.28E-02 & 1.80 & * \\
\hline Dist_Interstate & 1.69E-05 & 0.74 & & $1.65 \mathrm{E}-05$ & 0.72 & & $1.68 \mathrm{E}-05$ & 0.75 & \\
\hline Nuis_Interstate & 2.93E-02 & 0.77 & & $3.36 \mathrm{E}-02$ & 0.89 & & 3.41E-02 & 0.90 & \\
\hline Ln (Footage) & 9.97E-01 & 10.95 & $\star \star \star *$ & $1.00 \mathrm{E}+00$ & 11.15 & $\star \star \star *$ & $1.00 \mathrm{E}+00$ & 11.35 & $\star \star * *$ \\
\hline Ln (Lot size) & 2.52E-01 & 12.84 & $\star \star \star$ & $2.50 \mathrm{E}-01$ & 12.91 & $\star \star \star *$ & 2.49E-01 & 12.75 & $\star \star \star$ \\
\hline Baths2or3 & 7.38E-03 & 0.49 & & 3.33E-02 & 2.25 & ** & 2.94E-02 & 1.83 & * \\
\hline Baths3+ & 7.40E-02 & 2.69 & $\star \star \star *$ & 9.45E-02 & 3.60 & $\star \star \star *$ & $9.23 \mathrm{E}-02$ & 3.38 & $\star * \star$ \\
\hline Bedrooms4 & $-1.02 E-02$ & -0.72 & & $-4.23 E-03$ & -0.30 & & $1.05 \mathrm{E}-03$ & 0.07 & \\
\hline Bedrooms5+ & 5.10E-02 & 2.78 & $* \star *$ & 4.10E-02 & 2.19 & ** & 3.75E-02 & 2.05 & ** \\
\hline Age & $-5.38 \mathrm{E}-03$ & -3.32 & $\star \star \star *$ & $-4.55 \mathrm{E}-03$ & -2.91 & $* \star *$ & $-7.31 \mathrm{E}-03$ & -3.63 & $\star \star * *$ \\
\hline Age $^{2}$ & $6.23 \mathrm{E}-05$ & 4.06 & $\star \star \star ~$ & $5.47 \mathrm{E}-05$ & 3.73 & $\star \star \star *$ & $8.74 \mathrm{E}-05$ & 4.29 & 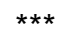 \\
\hline Constant & $2.97 \mathrm{E}+00$ & 4.54 & $\star \star \star$ & $2.96 \mathrm{E}+00$ & 4.60 & $\star \star \star *$ & $2.99 \mathrm{E}+00$ & 4.76 & $\star \star *$ \\
\hline Year dummies & yes & & & yes & & & yes & & \\
\hline Ln (Intensity $\left.{ }_{\text {New Const }}\right)$ & $-3.60 \mathrm{E}-01$ & -4.01 & $\star \star \star ~$ & $-2.74 \mathrm{E}-01$ & -2.90 & $\star \star \star *$ & $-1.72 \mathrm{E}-01$ & -1.40 & \\
\hline $25^{\text {th }}$ pctl - Ln (Intensity New Const ) & & & & $-1.06 \mathrm{E}-01$ & -5.12 & $\star \star \star *$ & $-9.44 \mathrm{E}-02$ & -3.88 & $\star * *$ \\
\hline Age*Ln (Intensity $\left.{ }_{\text {New Const }}\right)$ & & & & & & & $-6.88 \mathrm{E}-03$ & -1.86 & * \\
\hline $\operatorname{Age}^{2 *} \operatorname{Ln}\left(\right.$ Intensity $\left.{ }_{\text {New Const }}\right)$ & & & & & & & 7.31E-05 & 2.28 & ** \\
\hline Number of obs & 5165 & & & 5165 & & & 5165 & & \\
\hline R-squared & $75.85 \%$ & & & $75.99 \%$ & & & $76.07 \%$ & & \\
\hline
\end{tabular}


Table 8: Estimated Depreciation Effects

This table shows depreciation effect calculated as derivative with respect to age at different ages and for different intensities for Model 4 of Table 6 (Panel A) and for Model 3 of Table 7 (Panel B). Intensity Assessor is calculated as assessed value of the building divided by the assessed value of the lot. Intensity New Const $_{\text {is the }}$ ratio of interior square footage of subject property to the average interior square footage of new construction located within 1.25 miles of the subject property and sold within three years of the sale of the subject property. We test statistical significance of the linear combination of coefficients using an $\mathrm{F}$ test.

Panel A: Intensity Assessor $_{\text {in }}$

\begin{tabular}{|l|c|c|c|c|c|c|}
\hline & & & & Estimated \\
Age & Age Percentile & Intensity & Intensity Percentile & Depreciation Effect & F value & Pr $>$ F \\
\hline 10 & $<10^{\text {th }}$ & 0.283 & $10^{\text {th }}$ & $-0.0817 \%$ & 0.03 & 0.86 \\
\hline 10 & $<10^{\text {th }}$ & 0.859 & $50^{\text {th }}$ & $-0.3965 \%$ & 10.11 & $<0.01$ \\
\hline 10 & $<10^{\text {th }}$ & 1.757 & $90^{\text {th }}$ & $-0.5993 \%$ & 21.12 & $<0.01$ \\
\hline 19 & $10^{\text {th }}$ & 0.283 & $10^{\text {th }}$ & $-0.0228 \%$ & 0.05 & 0.83 \\
\hline 19 & $10^{\text {th }}$ & 0.859 & $50^{\text {th }}$ & $-0.2746 \%$ & 16.58 & 0.02 \\
\hline 19 & $10^{\text {th }}$ & 1.757 & $90^{\text {th }}$ & $-0.4368 \%$ & 31.31 & $<0.01$ \\
\hline 49 & $50^{\text {th }}$ & 0.283 & $10^{\text {th }}$ & $0.1736 \%$ & 14.08 & $<0.01$ \\
\hline 49 & $50^{\text {th }}$ & 0.859 & $50^{\text {th }}$ & $0.1317 \%$ & 22.18 & $<0.01$ \\
\hline 49 & $50^{\text {th }}$ & 1.757 & $90^{\text {th }}$ & $0.1047 \%$ & 9.38 & $<0.01$ \\
\hline
\end{tabular}

Panel B: Intensity ${ }_{\text {New }}$ Const

\begin{tabular}{|l|c|c|c|c|c|c|}
\hline Age & Age Percentile & Intensity & Intensity Percentile & $\begin{array}{c}\text { Estimated } \\
\text { Depreciation Effect }\end{array}$ & F value & Pr>F \\
\hline 10 & $<10^{\text {th }}$ & 0.335 & $10^{\text {th }}$ & $0.037 \%$ & 0.05 & 0.82 \\
\hline 10 & $<10^{\text {th }}$ & 0.588 & $50^{\text {th }}$ & $-0.269 \%$ & 7.68 & 0.01 \\
\hline 10 & $<10^{\text {th }}$ & 1.052 & $90^{\text {th }}$ & $-0.584 \%$ & 34.16 & $<0.01$ \\
\hline 19 & $10^{\text {th }}$ & 0.335 & $10^{\text {th }}$ & $0.050 \%$ & 0.14 & 0.71 \\
\hline 19 & $10^{\text {th }}$ & 0.588 & $50^{\text {th }}$ & $-0.181 \%$ & 5.25 & 0.02 \\
\hline 19 & $10^{\text {th }}$ & 1.052 & $90^{\text {th }}$ & $-0.420 \%$ & 28.53 & $<0.01$ \\
\hline 49 & $50^{\text {th }}$ & 0.335 & $10^{\text {th }}$ & $0.095 \%$ & 2.95 & 0.09 \\
\hline 49 & $50^{\text {th }}$ & 0.588 & $50^{\text {th }}$ & $0.110 \%$ & 11.76 & $<0.01$ \\
\hline 49 & $50^{\text {th }}$ & 1.052 & $90^{\text {th }}$ & $0.127 \%$ & 12.57 & $<0.01$ \\
\hline
\end{tabular}


Table 9: Models with Intensity ${ }_{\text {Assessor }}$ and percent of neighboring properties identified as teardowns: based on equation (12)

The sample includes single family residential properties sold between 1996 and 2007 in Greenwich, Connecticut. Dependent variable is Ln(Price). Explanatory variables are described in Tables 1 and 4. Standard errors where adjusted for spatial dependence by clustering into 65 grid squares. Robust t-statistics using Huber-White methods and spatial clustering are shown next to estimates of coefficients. ***, **, * indicate significance at $1 \%, 5 \%$ and $10 \%$, respectively.

\begin{tabular}{|c|c|c|c|c|c|c|c|c|c|c|}
\hline \multirow[b]{2}{*}{ Variable } & \multicolumn{2}{|c|}{ Model 1} & \multicolumn{2}{|c|}{ Model 2} & \multicolumn{2}{|c|}{ Model 3} & \multicolumn{2}{|c|}{ Model 4} & \multicolumn{2}{|c|}{ Model 5} \\
\hline & $\begin{array}{l}\text { Estimated } \\
\text { Coefficient }\end{array}$ & $\begin{array}{c}\text { Robust } \\
\text { T-statistic } \\
\end{array}$ & $\begin{array}{l}\text { Estimated } \\
\text { Coefficient }\end{array}$ & $\begin{array}{l}\text { Robust T- } \\
\text { statistic } \\
\end{array}$ & $\begin{array}{l}\text { Estimated } \\
\text { Coefficient }\end{array}$ & $\begin{array}{c}\text { Robust } \\
\text { T-statistic } \\
\end{array}$ & $\begin{array}{l}\text { Estimated } \\
\text { Coefficient }\end{array}$ & $\begin{array}{c}\text { Robust } \\
\text { T-statistic } \\
\end{array}$ & $\begin{array}{c}\text { Estimated } \\
\text { Coefficient }\end{array}$ & $\begin{array}{c}\text { Robust } \\
\text { T-statistic }\end{array}$ \\
\hline Dist_CosCob & $-7.52 \mathrm{E}-06$ & -2.59 ** & $-7.26 \mathrm{E}-06$ & -2.38 ** & $-5.90 \mathrm{E}-06$ & -1.96 * & $-5.74 \mathrm{E}-06$ & -1.91 * & $-5.74 \mathrm{E}-06$ & -1.92 * \\
\hline Dist_CosCob_D & $1.58 \mathrm{E}-01$ & $3.06 * * *$ & $1.61 \mathrm{E}-01$ & $2.90 * \star \star$ & $1.58 \mathrm{E}-01$ & $2.87 * * \star$ & $1.58 \mathrm{E}-01$ & $2.89 * \star \star$ & 1.57E-01 & $2.88 * \star \star$ \\
\hline Nuis_RailRD & $-6.56 \mathrm{E}-02$ & -1.96 * & $-5.78 \mathrm{E}-02$ & -1.70 * & $-7.28 \mathrm{E}-02$ & $-2.18 * \star$ & $-7.19 \mathrm{E}-02$ & $-2.17 * \star$ & $-7.05 E-02$ & -2.11 ** \\
\hline Dist_LISound & $-9.41 E-07$ & -0.08 & $-7.13 E-06$ & -0.44 & $-1.55 E-05$ & -0.97 & $-1.55 E-05$ & -0.97 & $-1.50 \mathrm{E}-05$ & -0.95 \\
\hline Sound view & 8.12E-02 & 2.1 ** & 7.01E-02 & 1.74 * & 5.71E-02 & 1.38 & 5.58E-02 & 1.35 & 5.58E-02 & 1.36 \\
\hline Dist_Interstate & 3.68E-05 & 1.67 & 4.01E-05 & 1.63 & 2.75E-05 & 1.11 & 2.73E-05 & 1.12 & 2.86E-05 & 1.17 \\
\hline Nuis_Interstate & 1.69E-02 & 0.41 & $1.59 \mathrm{E}-02$ & 0.35 & 9.63E-03 & 0.21 & 5.80E-03 & 0.13 & 8.50E-03 & 0.19 \\
\hline Ln (Footage) & $6.66 \mathrm{E}-01$ & $23.49 * * *$ & 6.83E-01 & $19.80 * \star \star$ & 6.57E-01 & $20.30 * \star \star$ & $6.76 \mathrm{E}-01$ & 19.26 *** & $6.80 \mathrm{E}-01$ & 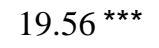 \\
\hline Ln (Lot size) & 2.69E-01 & $13.13^{* * \star}$ & 2.55E-01 & $11.29 * \star \star$ & 2.64E-01 & $11.80 * \star \star$ & $2.56 \mathrm{E}-01$ & $11.38 * \star \star$ & 2.52E-01 & $11.35 * \star \star$ \\
\hline Baths2or3 & $-1.51 \mathrm{E}-03$ & -0.1 & 1.49E-05 & 0.00 & $-2.98 \mathrm{E}-04$ & -0.02 & 1.95E-03 & 0.13 & 2.06E-03 & 0.13 \\
\hline Baths3+ & 7.44E-02 & $2.71 * * *$ & 7.25E-02 & $2.39 * *$ & $6.50 \mathrm{E}-02$ & 2.24 ** & 6.81E-02 & $2.29 * \star$ & 7.13E-02 & 2.39 ** \\
\hline Bedrooms4 & $-1.39 \mathrm{E}-02$ & -0.93 & $-2.64 \mathrm{E}-03$ & -0.21 & $-7.84 \mathrm{E}-03$ & -0.57 & $-6.83 E-03$ & -0.51 & $-4.29 \mathrm{E}-03$ & -0.33 \\
\hline Bedrooms5+ & 5.71E-02 & $2.89 * * *$ & 6.13E-02 & $3.02 * * *$ & 5.99E-02 & $2.94 * \star *$ & 6.14E-02 & $3.09 * * *$ & 6.01E-02 & $3.05 * * *$ \\
\hline Age & $-5.22 \mathrm{E}-03$ & $-3.04 * \star *$ & $-6.27 E-03$ & $-3.33 * \star \star$ & $-5.55 E-03$ & $-2.96 * \star \star$ & $-5.94 \mathrm{E}-03$ & $-3.17 * \star \star$ & $-6.33 E-03$ & $-3.35 * * \star$ \\
\hline Age $^{2}$ & $6.57 \mathrm{E}-05$ & $4.18 * \star \star$ & $7.58 \mathrm{E}-05$ & $4.44^{\star \star *}$ & 6.82E-05 & $4.09 * * \star$ & 7.17E-05 & $4.27 * \star \star$ & 7.65E-05 & $4.48 * \star \star$ \\
\hline Constant & $5.46 \mathrm{E}+00$ & $31.05 * \star \star$ & $5.56 \mathrm{E}+00$ & $27.62 * \star \star$ & $5.69 \mathrm{E}+00$ & 29.04 *** & $5.62 \mathrm{E}+00$ & 27.26 *** & $5.63 \mathrm{E}+00$ & $27.28 * \star \star$ \\
\hline Year Dummies & yes & & yes & & yes & & yes & & yes & \\
\hline Ln (Intensity Assessor ) & & & $6.40 \mathrm{E}-02$ & 1.87 * & & & $-2.87 \mathrm{E}-02$ & $-2.39 * \star$ & $6.46 \mathrm{E}-02$ & 1.90 * \\
\hline $\begin{array}{l}\text { Inten_Missing_BV } \\
25^{\text {th }} \text { pctl - }\end{array}$ & & & 2.02E-02 & 1.07 & & & 4.07E-02 & 1.37 & 2.67E-02 & 1.41 \\
\hline Ln (Intensity Assessor ) & & & $-4.31 \mathrm{E}-02$ & $-2.23 * \star$ & & & & & $-3.91 E-02$ & -1.95 * \\
\hline Age* $^{*} \operatorname{Ln}\left(\right.$ Inten $\left._{\text {Assessor }}\right)$ & & & $-3.35 E-03$ & $-2.61 * \star \star$ & & & & & $-3.20 \mathrm{E}-03$ & -2.52 ** \\
\hline Age $^{2 *} \operatorname{Ln}\left(\right.$ Inten $\left._{\text {Assessor }}\right)$ & & & 3.18E-05 & $2.57 * \star \star$ & & & & & 2.98E-05 & $2.46 * \star$ \\
\hline $\mathrm{P}_{\text {Teardown }}$ & & & & & $1.19 \mathrm{E}+00$ & $4.63 * \star \star$ & $1.15 \mathrm{E}+00$ & $4.40^{* \star *}$ & $1.12 \mathrm{E}+00$ & 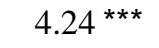 \\
\hline Number of obs & 4557 & & 4557 & & 4557 & & 4557 & & 4557 & \\
\hline R-squared & $73.46 \%$ & & $73.68 \%$ & & $73.70 \%$ & & $73.80 \%$ & & $73.89 \%$ & \\
\hline
\end{tabular}


Hedonic Pricing with Redevelopment Options

\section{Table 10: Robustness Tests with Ten Fold Cross Validation}

This table shows results from ten fold out-of-sample cross validation. The sample includes 5,218 single family residential properties sold between 1995 and 2007 in Greenwich, Connecticut. The sample was divided randomly into 10 nearly equal parts. One part was withheld and the models were estimated for the remaining 90\%. Estimated coefficients were used to predict the log of price for the withheld sample. The percentiles and mean of the absolute errors are shown below.

\begin{tabular}{lccc}
\hline & \multicolumn{2}{c}{ Mean of absolute errors of 10 out-of-sample estimates } \\
\hline Percentile points & $\begin{array}{c}\text { Standard Hedonic: } \\
\text { Model 1, Table 6 }\end{array}$ & $\begin{array}{c}\text { Hedonic with Option Value: } \\
\text { Model 4, Table 6 }\end{array}$ & $\begin{array}{c}\text { Best estimate, hedonic with } \\
\text { option value, equation (11) }\end{array}$ \\
\hline p10 & 0.03228 & 0.03365 & 0.03277 \\
p25 & 0.08365 & 0.08332 & 0.08362 \\
median & 0.18691 & 0.18535 & 0.18584 \\
mean & 0.26712 & 0.26643 & 0.26663 \\
p75 & 0.34142 & 0.34254 & 0.33924 \\
p90 & 0.56283 & 0.55722 & 0.56307 \\
& & & $75.72 \%$ \\
R-squared & $75.60 \%$ & $75.80 \%$ & \\
\hline
\end{tabular}

